NBER WORKING PAPER SERIES

\title{
TECHNOLOGY AND THE DEMAND FOR SKILL: AN ANALYSIS OF WITHIN AND BETWEEN FIRM DIFFERENCES
}

\author{
John M. Abowd \\ John Haltiwanger \\ Julia Lane \\ Kevin L. McKinney \\ Kristin Sandusky \\ Working Paper 13043 \\ http://www.nber.org/papers/w13043
}

\author{
NATIONAL BUREAU OF ECONOMIC RESEARCH \\ 1050 Massachusetts Avenue \\ Cambridge, MA 02138 \\ April 2007
}

The authors wish to acknowledge the substantial contributions of the Longitudinal Employer-Household Dynamics (LEHD) Program staff at the U.S. Census Bureau. This document reports the results of research and analysis undertaken by the U.S. Census Bureau staff. It has undergone a Census Bureau review more limited in scope than that given to official Census Bureau publications. This document is released to inform interested parties of ongoing research and to encourage discussion of work in progress. This research is a part of the U.S. Census Bureau's LEHD Program, which is partially supported by the National Science Foundation Grants SES-9978093 and SES-0427889 to Cornell University (Cornell Institute for Social and Economic Research), the National Institute on Aging Grant R01 AG018854, and the Alfred P. Sloan Foundation. The views expressed herein are attributable only to the authors and do not represent the views of the U.S. Census Bureau, its program sponsors or data providers. Some or all of the data used in this paper are confidential data from the LEHD Program. The U.S. Census Bureau supports external researchers' use of these data through the Research Data Centers (see www.ces.census.gov). For other questions regarding the data, please contact Jeremy S. Wu, Assistant Division Chief, LEHD Program, (Jeremy.S.Wu@ census.gov http://lehd.dsd.census.gov ). The views expressed herein are those of the author(s) and do not necessarily reflect the views of the National Bureau of Economic Research.

(C) 2007 by John M. Abowd, John Haltiwanger, Julia Lane, Kevin L. McKinney, and Kristin Sandusky. All rights reserved. Short sections of text, not to exceed two paragraphs, may be quoted without explicit permission provided that full credit, including (C) notice, is given to the source. 
Technology and the Demand for Skill:An Analysis of Within and Between Firm Differences John M. Abowd, John Haltiwanger, Julia Lane, Kevin L. McKinney, and Kristin Sandusky NBER Working Paper No. 13043

April 2007

JEL No. J23,J24,O33

\begin{abstract}
$\underline{\text { ABSTRACT }}$
We estimate the effects of technology investments on the demand for skilled workers using longitudinally integrated employer-employee data from the U.S. Census Bureau's Longitudinal Employer-Household Dynamics Program infrastructure files spanning two Economic Censuses (1992 and 1997). We estimate the distribution of human capital and its observable and unobservable components within each business for each year from 1992 to 1997 . We measure technology using variables from the Annual Survey of Manufactures and the Business Expenditures Survey (services, wholesale and retail trade), both administered during the 1992 Economic Census. Static and partial adjustment models are fit. There is a strong positive empirical relationship between advanced technology and skill in a cross-sectional analysis of businesses in both sectors. The more comprehensive measures of skill reveal that advanced technology interacts with each component of skill quite differently: firms that use advanced technology are more likely to use high-ability workers, but less likely to use high-experience workers. These results hold even when we control for unobservable heterogeneity by means of a selection correction and by using a partial adjustment specification.
\end{abstract}

John M. Abowd

CISER

391 Pine Tree Road

Cornell University

Ithaca, NY 14850

and NBER

John_Abowd@cornell.edu

John Haltiwanger

Department of Economics

University of Maryland

College Park, MD 20742

and NBER

haltiwan@econ.umd.edu

Julia Lane

University of Chicago - NORC

lane-julia@norc.uchicago.edu
Kevin L. McKinney

California Census Research Data Center

University of California, Los Angeles

4250 Public Policy Building

Los Angeles, CA 90095

kevinm@ccrdc.ucla.edu

Kristin Sandusky

U.S. Bureau of Census

4700 Silverhill Road

Suitland, MD 20233

lee.k.sandusky@census.gov 


\section{Introduction}

"...the widespread introduction of new technology has brought new employment opportunities and rising relative wages to those with the highest levels of human capital. However, this new technology has also helped to bring about higher than normal job losses, particularly among unskilled workers, and put a premium on being able to adapt to new workplace challenges."1

How sensitive is the demand for skilled workers to technological change? How sensitive is the demand for unskilled workers? Since skill has different dimensions - partly experience and partly basic ability-how is the demand for different types of skill affected? Progress on answering these questions has been limited by substantial empirical challenges. The appropriate unit of analysis is the firm, yet traditional measures of human capital at the firm level are limited, and difficult to decompose into experience and ability. In addition, detailed firm-level measures of technology are difficult to obtain. Finally, it is rare to have longitudinal data that permit an examination of changes in the way that firms behave over time.

This paper uses new data that remedy many of these deficiencies. We exploit innovative measures of human capital that permit the identification of different dimensions of skill—both observable and non-observable. We use these to create detailed multi-dimensional statistics of the human capital composition of a firm's workforce. We then match this firm-level information with other data that includes information about a firm's inputs and outputs, including the use of advanced technology. We use these skill data, wage rates, output measures, and technology variables to directly examine the way in which technology differences across businesses affect the types of workers that are employed in the current and following years.

Consistent with the related literature, we find a strong empirical relationship between technology and skill in a cross-sectional analysis of firms. The richness of our data allows us to take a step beyond this literature, however, to examine how various components of skill interact with technology. We find that technology interacts quite differently with each skill component. Firm-level technology investments in capital such as computers and software are positively linked to overall human capital and unobservable individual ability, but not to measured experience. Indeed, we find evidence that the demand for experience is inversely related to the adoption of advanced technology. We are able to make this distinction because our data allow us

\footnotetext{
${ }^{1}$ Ehrenberg and Smith (2005), from the online summary of Chapter 15, "Unemployment" available at http://wps.aw.com/aw_ehrensmith_mlaborecon_9/0,10673,2205850-,00.html. (cited March 4, 2007).
} 
to estimate and decompose human capital into unobservable person effects and measured experience effects. In addition, we address another empirical problem encountered by all related research; the problem of unobserved factors linking the choice of technology to workforce skill demand. Specifically, we use the longitudinal nature of the data to exploit our knowledge of firm survival (which is likely to be linked to these unobserved traits) to control for firm deaths in our cross sectional analysis. We also conduct a partial adjustment dynamic analysis to explore how firms' actual and desired demand for skills evolve over time.

The paper proceeds as follows. In section 2, we briefly review the recent literature and discuss the underlying conceptual framework. Section 3 describes the data and the measures of technology and skill used in the analysis. Section 4 provides basic facts about skill, technology and technology bundling in the data. Section 5 is the core of the paper including the estimation of the relationship between the demand for skill and technology. Concluding remarks are provided in section 6 .

\section{Background and Conceptual Framework}

The availability of longitudinally matched employer-employee data permits the generation of new insights into the relationship between technology and skill at the firm level. As noted in the introduction, earlier work has faced substantial empirical impediments. Although the unit of analysis should ideally be the firm, researchers have often been forced to use industry, rather than firm-level data, and the data have often only been available in manufacturing. In addition, researchers using such industry data have only had crude measures of human capital available to them. Conversely, researchers using individual-level data, with richer measures of human capital, have had access to very limited information on the firms at which workers are employed.

\subsection{Summary of Major Previous Studies in Relation to This Paper}

The ideas pursued here have roots in several literatures. One literature examines the evolution of businesses within industries. This work relates technological change, including the adoption and diffusion of new technologies (broadly defined) with the associated organizational changes, including the demand for skilled workers. ${ }^{2}$ The other strain focuses on the implications of these changes for the evolution of wage inequality, which we will not elaborate in this paper.

\footnotetext{
${ }^{2}$ Relevant papers include Autor, Katz and Krueger (1998), Bartel and Lichtenberg (1987), Berman, Bound and Griliches (1994), Bresnahan, Brynjolfsson and Hitt (2002), Caballero and Hammour (1994), Campbell (1998),
} 
We begin by reviewing the major industry-level time series evidence on the relationship between technology and skill. Berman, Bound and Griliches (1994) used four-digit data from the Annual Survey of Manufactures for 1959 to 1989, which were augmented to include measures of the capital stock and price indices for the inputs, to examine the changing demand for skills in response to changes in technology. Their measure of skill was the ratio of non-production to production workers. ${ }^{3}$ They found that the increased use of non-production workers within manufacturing industries was directly related to the increased investment in computers and research and development. Very little of the increase was associated with increased demand for goods produced by non-production worker intensive manufacturing industries. ${ }^{4}$ Micro-data on individuals have also been used extensively to create industry and industry-occupation time series to study the impact of technology on the demand for skilled workers. While such data inherently miss important features of the relationship that can only be captured using enterprise or establishment micro-data, it is important to note the major contributions from this source. Autor, Katz and Krueger (1998) studied the period from 1940 to 1996, measuring skill with educational attainment as reported in the decennial Censuses of Population and Housing PublicUse Micro Samples and the Current Population Surveys (CPS), aggregated to the industry level. They added computer-use data from the October CPS, and three other sources, as a technology measure. They found that the rate of skill upgrading was greatest in industries that were more computer intensive, which they interpreted as supporting the complementarity of education and information technology.

Integrated employer-employee micro-data are still relatively rare but have already been used to study problems like the ones we pose here. Although the focus of their study was the relation between human resource management (HRM) practices and productivity, Ichniowski, Shaw and Prennushi (1997) provided direct evidence on skill-technology trade-offs for the single type of steel finishing process they studied. They used extensive production-line longitudinal data, collected on site, for the specific technologies adopted and the HRM practices used. Their

Chari and Hopenhyn (1991), Caselli (1999), Davis and Haltiwanger (1999), Doms, Dunne and Troske (1997), Dunne, Roberts and Samuelson (1989), Dunne, Haltiwanger and Troske (1997), Haltiwanger, Lane and Spletzer (forthcoming), Hellerstein, Neumark, and Troske (1999), Ichniowski, Shaw and Prennushi (1997), Jovanovic and MacDonald (1994), Juhn, Murphy and Pierce (1993), Katz and Murphy (1992), and Kremer and Maskin (2000).

${ }^{3}$ These data are now known as the NBER-CES Manufacturing Industry Database (Bartelsman, Becker and Gray, 2000).

\footnotetext{
${ }^{4}$ Dunne, Haltiwanger and Troske (1997), using establishment-level micro-data, were also forced to use the same crude measure of skill.
} 
employee skill variables included directly measured recruitment and training components of the HRM system. They concluded that a particular combination of "high-performance" HRM practices, which included selection and training of skilled workers, was highly complementary with the successful adoption and integration of information-technology intensive capital investments. Bresnahan, Brynjolfsson and Hitt (2002) directly studied the complementarities between employee skill and information technology capital for the period from 1987 to 1994. Their employee skill measures included education, occupation, and an employer-assessed "skill level of work" variable data that came from a single cross-sectional survey of organizational practices and labor force characteristics conducted in 1995 and 1996. They merged longitudinal data on information technology capital, measured for the same organizations as completed the cross-sectional organization survey, with enterprise-level financial data from Compustat to construct their other measures of inputs and output. Their study comprised the about 300 large, publicly-traded firms. They found that increased use of information technology capital was directly related to increased demand for skilled employees. Hellerstein, Neumark, and Troske (1999) used a cross-section of integrated employer-employee data based on matching the 1990 Census of Population and Housing long form data with data from the 1989 Annual Survey of Manufactures. Their worker skill measures included education, occupation, and age. Their technology measure was the capital stock that has been developed for the ASM establishments, which is the same capital stock measure we use in this paper. Although the focus of their study was on estimating the difference between pay and marginal productivity, they do provide some mixed evidence about the complementarity of capital and skilled labor, which is positive in their main analysis (Table 3), but negative in other specifications (Table 4).

Largely based on establishment-level micro-data, the growing literature on firm dynamics makes clear that there is tremendous between-firm heterogeneity in choices of technology (see, e.g., Doms, Dunne and Troske, 1997, Dunne, Haltiwanger, and Troske, 1997, and Haltiwanger, Lane and Spletzer, forthcoming). In addition, Haltiwanger, Lane and Spletzer (forthcoming) found that firms are remarkably heterogeneous in the ways in which they organize themselves and that heterogeneity is remarkably persistent. Thus, much change occurs not because existing firms reorganize their existing production, but rather because new firms enter and displace old firms, or because firms with successful production techniques expand at the cost of their less successful, contracting, counterparts (Foster, Haltiwanger and Krizan, 2001). 
There have clearly been important strides in advancing our understanding of the relationship between technology, organization and the demand for skilled workers, measuring technology at the firm level and measuring human capital using observable workforce characteristics. For clarity, we summarize here the differences in our analysis in comparison to this previous literature. Unlike Berman et al. and Autor et al., we use micro-data and not industry-level time series. In contrast with all of the studies mentioned above, our measure of employee skills is based upon both observable and unobservable (to the statistician) components of human capital. The unobservable component is derived from the estimated person effects in a longitudinal wage equation that also includes employer heterogeneity. In our data, the effect of education on wages is captured by this person effect and is not measured directly. Like Hellerstein et al. (for observables), but unlike the other studies above, we summarize the entire distribution of human capital and its components within each business unit. Like Ichniowski et al. and Bresnahan et al., our analysis is at the business-unit level; however, we use a pseudoestablishment - either a single establishment or the aggregation of all establishments owned by the enterprise and operating in the same county and two-digit SIC. Our workforce skill data are available for each year from 1992 to 1997. Output and capital are only available in the Economic Census years 1992 and 1997. Information technology investments are only available in the survey year 1992 (Annual Survey of Manufactures and Business Expenditures Survey). So, this component of our analysis is the mirror image of Bresnahan et al., who used longitudinal data on the information technology variables but cross-sectional data on the employee skill measures. Our analysis sample is based on three large states (California, Florida and Illinois), unlike the ones cited above which were national samples of the U.S., except for Bresnahan et al., who used a convenience sample. However, even though the Hellerstein et al. study used a national frame, there were serious data integration limitations in the methodology used to create their data. ${ }^{5}$ Consequently, our study includes four times as many establishments, establishments from both manufacturing and services (including trade), and characteristics of the employees that are based on the universe of workers, rather than a one-in-six sample, who were integrated using both identifier and probabilistic record linking methods. To aid comparison with national samples, we constructed appropriate weights.

\footnotetext{
${ }^{5}$ These data are known as the Worker-Establishment Characteristics Database (Troske 1998). See the discussion in Abowd and Kramarz (1999).
} 
To fully implement our research model, we must derive the relationship between skill demand and technology at the firm level in a manner that accommodates measuring the distribution of skills, both observable and unobservable within the firm. Then we must derive an explicit empirical representation of that relationship. The new measures of individual skill must be empirically summarized at the firm-level. Finally, we must account for the timing of our firmlevel measures of technology in the empirical analysis. The remaining sub-sections provide details on our approach to each of these challenges.

\subsection{Describing the Relation between Technology and the Demand for Human Capital at the}

\section{Firm Level}

Although not mutually exclusive, technology adoption can occur in two ways: new firms that enter can have different levels of technology than do the ones that exit, and/or continuing firms can change the way in which they do business. Thus, there are two ways to examine the impact on human capital. In the first case, we can examine between-firm changes in technology, paying particular attention to firm entry and exit dynamics, and relate that to between-firm changes in human capital. The second case can be investigated by examining within-firm changes in technology and relating them to within-firm changes in human capital.

Our theoretical approach is based on a simple model of workforce choice as a function of technology (broadly defined). Suppose firms are faced with a production relationship given by:

$$
y_{j t}=F\left(Z_{j t}, L_{1 j t}, \ldots, L_{B j t}\right)
$$

where $y_{j t}$ is output for firm $j$ in period $t$, the vector $Z_{j t}$, indexes the state of technology including tangible and intangible capital (like organizational capital), and $L_{b j t}$ is the number of workers of type $b$, where $b$ indexes both observable and unobservable characteristics. Treating $Z$ as quasifixed, cost minimization for a given output level yields (using Shepherd's lemma) the generalized demand for workers of type $b$ as given by:

$$
S_{b j t}=S\left(Z_{j t}, y_{j t}, w_{1 j t} / w_{B j t}, \ldots, w_{b j t} / w_{B j t}, \ldots\right)
$$

where $S_{b j t}$ is the share (or perhaps cost share depending upon the specific functional form for $F$ ) of type $b$ workers, $b=1, \ldots, B$, and $w_{b j t}$ is the appropriate shadow wage rate of type $b$ workers. ${ }^{6}$

\footnotetext{
${ }^{6}$ Note that the shadow wage may differ from the actual wage due to bargaining, internal labor market and/or rent sharing behavior. Our proposed analysis of earnings dynamics described below will shed light on internal labor market and rent sharing considerations.
} 
In this framework, the demand for workers of type $b$ by a particular firm depends upon the type of technology adopted $(Z)$, the nature of the firm-worker type complementarities, the scale of operations and the relative shadow wages. In considering the implications, it is important to emphasize that there are many reasons that firms, even within the same industry, adopt different technologies. For example, $Z$ may reflect differences in managerial/entrepreneurial ability, vintage, location, or other aspects of physical and intangible capital. As a result, not only will firms within the same industry exhibit heterogeneity in their demand for workers of type $b$ but this heterogeneity may vary over time as conditions (e.g., available technologies or other cost or demand shocks) change and due to firm life cycle effects.

The empirical implementation is based on various specifications of this simple model, namely:

$$
S_{b j t}=\alpha_{0}+\sum_{k} \alpha_{1 k} Z_{k j t}+\sum_{b} \alpha_{2 b} \ln \left(w_{b j t} / w_{B j t}\right)+\alpha_{3} \ln y_{j t}+v_{b j t}
$$

where the coefficients $\alpha_{1 k}$ indicate the effect of different types of technology capital, Z; the remaining coefficients have the conventional share equation interpretation, and $v_{b j t}$ is the share error term. The coefficient estimates from cross sectional (or pooled cross sectional data) will shed light on how observable indicators of technology $Z$ are related to human capital across businesses.

There is a clear challenge associated with estimating equation (3); unobserved factors are likely correlated with both the level of skills and the level of technology selected by the business. For example, high ability managers may be more likely to both use the latest technology and implement the best business models, including organizational and human resource practices. Thus, the coefficient estimates for a particular component of measured $Z$ from the level specification may reflect difficult-to-measure firm effects rather than the independent contribution from the measured $Z$ itself. In the absence of suitable plant-level instruments, we pursue an approach in the spirit of Ericson and Pakes (1995) and Olley and Pakes (1996). In particular, we argue that many of these unobserved traits are likely to be linked with business survival: exiting businesses are likely to have characteristics that influence the level of skills and technology that are inherently different than the businesses that are continuers. Accordingly, equation (3) is also estimated using a selection correction to control for such unobserved heterogeneity that is correlated with survival. 
Equation (2) may be thought of as the desired, rather than actual, skill demand relationship. Since it may take time for actual skill mix to equal desired skill mix, a simple partial adjustment model that might capture this relationship is given by:

$$
\Delta S_{b j t}=\lambda\left(S_{b j t}^{*}-S_{b j t-1}\right)
$$

or, equivalently,

$$
S_{b j t}=\lambda S_{b j t}^{*}+(1-\lambda) S_{b j t-1}
$$

where the asterisk designates that we are characterizing desired skill, $S^{*}$. In equation (5) skill usage in period $t$ is determined by a weighted average of the desired level of skill and the actual level of skill last period, with the value of $\lambda$ determining how rapidly a firm's actual skill mix approaches the desired level. For example, when $\lambda=1$, the adjustment process occurs quickly, within one period, but the closer $\lambda$ is to zero, the more periods the adjustment process takes to converge. By recursive substitution, we have:

$$
S_{b j t}=\lambda S_{b j t}^{*}+\lambda(1-\lambda) S_{b j t-1}^{*}+\ldots+\lambda(1-\lambda)^{k-1} S_{b j t-k+1}^{*}+(1-\lambda)^{k} S_{b j t-k}
$$

The empirical challenge in our application is that we observe the sequence of actual $S_{b j t}$ each year. However, we only observe all of the variables used to construct $S_{b j t}^{*}$ in the base Economic Census year 1992. Although a subset of the variables used to construct $S_{b j t}^{*}$ is present in the intercensal years, critical variables are not collected outside the Economic Census. We address this data deficiency by noting that a reasonable empirical approximation to $S^{*}$ in the current year might be $S^{*}$ in the base year. For example, the underlying innovations driving $S^{*}$ could be modeled as random walk:

$$
S_{b j t}^{*}=S_{b j t-1}^{*}+\varepsilon_{b j t}
$$

where $\varepsilon_{b j t}$ is white noise. Such a partial adjustment framework permits the estimation of a series of dynamic specifications driven by base year measures. Substituting equation (7) into equation (3) yields the partial adjustment skill demand estimating equations:

$$
\begin{aligned}
S_{b j+\tau} & =\lambda\left(\sum_{\ell=1}^{\tau}(1-\lambda)^{\ell-1}\right)\left(\alpha_{0}+\sum_{k} \alpha_{1 k} Z_{k j t}+\sum_{b} \alpha_{2 b} \ln \left(w_{b j t} / w_{B j t}\right)+\alpha_{3} \ln y_{j t}\right) \\
& +(1-\lambda)^{\tau} S_{b j t}+\sum_{\ell=1}^{\tau} \lambda(1-\lambda)^{\ell-1} \sum_{m=1}^{\ell} \varepsilon_{b j t+m}+v_{b j t}
\end{aligned}
$$


for $t=1992$, and $\tau=1, \ldots, 4$, which correspond to the intercensal years for which data on $Z_{j t}$ and $y_{j t}$ are unavailable. In particular, if technology spending and skill demand are positively related and if businesses adjust their skill mix gradually over time, then the coefficients on the technology variables should increase in magnitude over time because for each additional year $t+\tau$ we go forward, an additional $(1-\lambda)^{\tau-1}$ times the original effect of a demand variable accumulates in the share of $S_{b j t+\tau}$. In other words, an examination of the coefficient pattern over longer and longer horizons following the information technology investment should reveal the long run effect of variation in $Z$ on $S^{*}$.

Another empirical challenge in implementing the partial adjustment specification occurs because while estimates must be derived from businesses that exist in both periods for which the analysis is based, non-surviving businesses also account for variation in the demand for labor. Thus, the estimation of equation (8) yields inferences on the impact of base year technology on the demand for skills in later years conditional not only on the demand for skills in the base year but also conditional on the continuing viability of the business. The resulting selection bias in this dynamic labor setting is analogous to the one considered in Audretsch and Mahmood (1995) and Abowd, Crépon and Kramarz (2001). Our approach is to estimate equation (8) correcting for selection in a manner similar to their methods, and to compare those results with uncorrected least squares estimates.

\subsection{Measuring Human Capital at the Firm Level}

One of the limitations of the existing literature relating changes in technology to skill is that the measures of skill are quite limited. As noted above, the measure most often used from firm-level data is quite crude - the ratio of production to non-production workers. Even for household-level data, the usual skill variables (e.g., education and experience) capture only limited and imperfect dimensions of skill. Thus, many studies conclude (e.g., Juhn, Murphy and Pierce, 1993) that it is the unobserved dimensions of skill that are most important for understanding the changing demand for skills in the workplace. This paper exploits the new techniques developed by Abowd, Kramarz and Margolis (1999) together with very rich matched longitudinal data on both firms and workers to identify the unobserved components of worker skill. 
The Abowd, Kramarz and Margolis decomposition of log wages for individuals is: ${ }^{7}$

$$
\ln w_{i t}=\theta_{i}+\psi_{\mathrm{J}(i, t)}+x_{i t} \beta+\varepsilon_{i t}
$$

where the dependent variable is the log fulltime, full year wage rate of an individual $i$ working at time $t$ and the function $\mathrm{J}(i, t)$ indicates the employer $j$ of individual $i$ at date $t$. The first component of equation (9) is the time invariant person effect, the second component is the time-invariant firm effect, the third component is the contribution of time varying observable individual characteristics, and the fourth component is the statistical residual, orthogonal to all other effects in the model. ${ }^{8}$

The fixed worker effect $\theta$ plus the experience component of $x \beta$ comprise the core measure of human capital, called " $H$ ". ${ }^{9}$ The human capital measures can be thought of as the market value of the portable component of an individual's skill. They have two components: an individual or person effect, which does not vary over time and a component based on labor market experience. The individual effect includes some factors that are often observable to the statistician, such as years of education and sex; and some factors that are often not, such as innate ability, "people skills," "problem solving skills," perseverance, family background, and educational quality. The experience component is directly calculated from the data, and, as such, is left censored at the start of the data period. ${ }^{10}$

The econometric methodology and estimates of human capital, $H$ and its components, used in this paper are discussed and described in detail in Abowd, Lengermann and McKinney (2003, hereafter ALM). There are a number of interesting findings for the period 1992-1997 that are relevant to this study.

First, ALM find that the new measures capture a much broader array of skills than do traditional measures. The proportion of earnings variation that can be explained using this type of approach is about $84 \%$. And, in matches to the Current Population Survey-the basis for much

\footnotetext{
${ }^{7}$ The vector $x$ has a number of other controls including time effects and full quarter employment adjustments.

${ }^{8}$ When estimating the wage decomposition in equation (9), we use only dominant employer earnings, defined as the job (person firm match) in a given year with the highest earnings. This restriction results in only one employer per person per year.

${ }^{9}$ It is worth noting that because the specification is in logs the human capital measure is relative, not absolute. That is, in comparing two workers who differ in $H$ by 0.1 we would say that the two workers differ in human capital by ten log points (approximately ten percent).

${ }^{10}$ This left-censoring is ameliorated by estimating the number of years of labor force experience an individual accumulates prior to the first appearance in the data.
} 
analysis of earnings and employment outcomes-they find that only a small fraction of the person specific effects can be explained by education, sex, and race.

Second, they find that although the overall distribution of human capital shifted to the right over the time period considered, the effects of the different subcomponents of skill are very different. The shift to the right was substantially due to changes in the person effect dominating changes in the experience effect: entering workers, while generally less experienced than continuing workers, were otherwise more highly skilled. Finally, they found a marked tendency for firms - both economy-wide and within the same industry - to hire either relatively high skilled workers or low skilled workers, rather than hire large amounts of workers in the middle part of the distribution.

These interesting results suggest that the empirical implementation of equations (3) and (8) should incorporate the overall measure of human capital and its separate components. The empirical implementation also requires converting measures calculated at the individual level to firm-level proportions that denote shares $(S)$ of particular types of skill. In order to implement this conversion, we follow ALM's approach and generate economy-wide distributions of each skill measure in the reference year 1992 for all jobs active at the end of quarter $1 .{ }^{11}$ Using these economy-wide distributions, we then calculate the threshold for each quartile of the distribution. Notice that these thresholds are fixed and determined by the reference year's labor market. Next, we generate firm-level kernel density estimates of the distribution of each skill measure. These firm-level estimates of the distribution of human capital, and its components, are estimated separately each year that a firm appears in the estimation sample. The measure of the proportion of highest-skill workers in a firm is then defined to be the proportion of the firm-level workforce that is above the economy-wide $75^{\text {th }}$ percentile vis-à-vis the reference year 1992. In this manner, a firm that increases its demand for the highest-skill workers will display an increased proportion of employment in this top quartile over time. Similarly, the proportion of the firm's workforce

\footnotetext{
${ }^{11}$ Quarterly earnings are reported by each covered firm regardless of whether a person worked for one day or for the entire quarter. For firms with a high level of worker inflows and/or outflows, the total number of employees at a point in time is likely to be significantly smaller than the number of employees that ever worked at the firm during the quarter. To more accurately represent the skill distribution on a given day, we use an end-ofquarter employment measure. A worker is employed at the end of quarter one if earnings are positive at the same firm in both quarter one and quarter two of that year. We also use all possible jobs when constructing our firm skill measures. Although only dominant jobs are used in the estimation of equation (9), we assume that a worker's skill is transferable across employers and use this information when calculating each firm's skill distributions.
} 
that is below the economy-wide $25^{\text {th }}$ percentile for the reference year is used as a measure of the proportion of lowest-skill workers.

\subsection{Measuring Technology at the Firm Level}

Another empirical challenge is developing direct measures of technology, particularly ones that are comparable across sectors. Clearly, physical capital intensity is a natural candidate, as are direct measures of the use of information technology such as computers or computer software. In addition, changes in other observable dimensions of a firm's activity may prove useful. For example, since information technology has been associated with a variety of changes in the manner of doing business, variation in the relation between inventory and sales might prove a useful indicator of changes in supply chain management technology.

Several quite interesting direct measures of technology are available, and are described in what follows. However, in common with the rest of the literature, much is left unmeasured, especially with regard to the intangible capital components of technology. An indirect way of capturing some firm heterogeneity is to use the firm effects from the estimated wage decomposition in equation (9), $\psi_{\mathrm{J}(i, t)}$. These reflect the component of the wage rate that is due to unmeasured firm heterogeneity. Such firm effects presumably reflect many factors, one of which is rent sharing - that is, firms may share rents from high levels of profitability/productivity, which may in turn be related to the type of technology (broadly defined) that has been implemented at a business. Including the firm effect in a regression, then, permits an indirect assessment of difficult-to-measure components of the technology of a business, for which the firm effects serve as a potential control. ${ }^{12}$

\section{Data Sources and Processing}

The analysis in this paper is made possible by new Census Bureau data ${ }^{13}$ that are derived from the Longitudinal Employer-Household Dynamics Program, (LEHD) infrastructure file system. This file system integrates information from state unemployment insurance data with Census Bureau economic and demographic data. ${ }^{14}$ Such integrated data permit the construction

\footnotetext{
${ }^{12}$ Of course, the latter connection is interesting in its own right given the open question of whether high human capital businesses also have high firm effects.

${ }^{13}$ The data development has been generously supported by both the National Science Foundation and the National Institute on Aging as part of a social science database infrastructure initiative.

${ }^{14}$ See Abowd et al. (forthcoming) for a description of the infrastructure file system structure, and Abowd, Haltiwanger and Lane (2004) for an overview of the LEHD data development effort. The methodology used to test the integrity of the individual identifier system is described and analyzed in Abowd and Vilhuber (2005), The
} 
of longitudinal information on workforce composition at the employer level. The LEHD Program represents a substantial investment made by the Census Bureau in order to permit direct linking of its demographic surveys (household-based instruments) with its economic censuses and surveys (business and business unit-based surveys).

\subsection{Unemployment Insurance Wage Records and ES-202 Data}

The unemployment insurance (UI) wage records are discussed in more detail in Abowd et al., (forthcoming), but a brief overview is provided here. To manage its Unemployment Insurance program, the Employment Security Agency in every state collects quarterly employment and earnings information. The quarterly wage reports, which contain a record for every employer-employee pair, enable us to construct a longitudinal data set on employers. ${ }^{15}$ The employer's four-digit Standard Industrial Classification is then added from another administrative file, the Quarterly Census of Employment and Wages (QCEW) also known as the EQUI report from the ES-202, collected as a part of the state's employment security program. According to the BLS, which cooperates with the states to develop coding standards for the QCEW, 98\% of all private, non-agricultural employment is covered by employer reports. ${ }^{16}$ The advantages of the UI wage record database are numerous. The data are frequent, longitudinal, and essentially universal for covered employment. The sample size is generous and earnings reports are more accurate than survey-based data. The advantage of having virtually universal coverage is that movements of individuals to different employers and the consequences of those moves on earnings can be tracked. It is also possible to do longitudinal analysis using the employer as the unit by selecting businesses that qualify for a particular analysis, then reconstructing their complete employee rosters at every point in time the firm had positive employment.

An important limitation of the UI wage records as maintained by the individual states is the lack of any demographic information on employees. The links to Census Bureau data overcome this limitation in two distinct ways. First, the micro-data are linked to administrative data at the Census Bureau containing information such as date of birth, place of birth, and sex for

methodology used to test the integrity of the business identifier system is described and analyzed in Benedetto et al. (forthcoming).

${ }^{15}$ When computing the wage decomposition we use all available data for three states: California 1992-2002, Florida 1993-2002, and Illinois 1990-2002. Florida data for 1992 are not available and we used 1993 skill distributions instead. All other Florida data for 1992 were measured in 1992.

${ }^{16}$ See BLS Handbook (2007), Chapter 5, page 4. This chapter was last revised in 1997. 
almost all workers in the dataset. Second, as discussed in the previous section, the staff at the LEHD program have exploited the longitudinal and universal nature of the data to estimate fixed worker and firm effects, according to an exact least squares solution of equation (9). ${ }^{17}$

\subsection{Economic Census and Business Survey Data}

The information in the UI wage records is also quite limited with regard to characteristics of the employer. We overcome this by linking the UI data to detailed information on individual firms available in each of two economic Census years (1992 and 1997). The analytical datasets that we constructed from these merged files have the employer as the unit of analysis. We measure many key variables; output, the distribution of human capital within a business, employment, wages, entry, exit, and also some proxies for $Z$ (see below). The measures of human capital within the business were constructed using the methodology described in section 2. In particular, for each firm, a measure of the share of its workforce in each year from 1992 through 1997 that is drawn from each quartile of the economy-wide human capital distribution is constructed. These four human capital summary statistics are constructed for each of the three measures of human capital: overall, the person effect component and the experience component.

The measures of $Z$ (i.e., observable measures of technology) are derived from information collected from the Economic Censuses, although the availability varies by sector and by year. One of the two primary sources for this information is the subset of businesses in the Manufacturing Economic Census who are also in the Annual Survey of Manufactures (ASM). ASM businesses are asked a set of detailed questions that enhance the basic information covered in the census. Similarly, a subset of non-manufacturing businesses (i.e., retail trade, wholesale trade and services) in the Economic Censuses is sampled in the Business Expenditures Survey (BES). We will refer to the sectors covered in the BES as "services." The questions in the BES are similar to those asked in the ASM.

Several different measures of 1992 technology are constructed. Three measures reflect the use of newer, more computer-oriented technologies: investment in computers as a proportion of overall equipment investment, spending on computer software and data processing services as a proportion of annual sales, ${ }^{18}$ and total inventories as a proportion of sales. ${ }^{19}$ More traditional

\footnotetext{
${ }^{17}$ The computational methods are described in Abowd, Creecy, and Kramarz (2002). Software and technical documentation available at http://lservices.ciser.cornell.edu/cg2/html/index.html (cited March 4, 2007).

${ }^{18}$ The measure of computer investment is the same as used in Autor, Katz and Krueger (1998) at an aggregate, industry level and by Dunne, Foster, Haltiwanger and Troske (2000) at a micro level.
} 
measures of technology use, such as the capital stock per worker, are also used. All but the computer investment question is asked again in 1997 for ASM businesses; unfortunately neither the computer investment nor the capital intensity measures can be constructed in 1997 for BES businesses. The lack of computer investment data in 1997 is a substantial limitation and is the primary reason that we focus the cross-sectional analysis on 1992 and do not investigate the relationship between changes over time in technology and skill.

Of course, in spite of this diversity of available technology measures, there remain many aspects of technology use that we are not able to quantify. One possibility is that many of these unobserved traits are correlated with the time-invariant firm effect, $\psi_{\mathrm{J}(i, t)}$. For this reason, $\psi_{\mathrm{J}(i, t)}$ is included as a proxy for technology that cannot be directly measured. The firm effect, although a useful control, captures many other potential factors so that caution is required in interpreting the impact of this variable.

\subsection{Construction of the Ex Post Weight}

A major technical issue related to the analytical sample is the construction of an ex post weight that corrects for the fact that our estimation sample is based upon human capital measures for aggregated business entities, which relate to unemployment insurance accounts and workplace locations, whereas other data come from the Census Bureau's economic censuses and surveys, which have a frame based on the Business Register. To correct for this feature of the analysis sample, we construct pseudo-establishments from the ES-202 data that can be related to similarly constructed entities from the Business Register.

The ES-202 based-establishments are aggregated to a unit based on the Federal Employer Identification Number (EIN), state, county, and industry (two-digit SIC). These identifiers are also present on the Business Register, where they are used to form similar entities. The resulting entities can be used to form a crosswalk between the ES-202 and the Business Register. The resulting crosswalk allows the linkage of the human capital distributions to the data from the Economic Censuses, ASM and BES. Thus, the unit of analysis is a pseudo-establishment. Within a particular state, single-unit employers in the ES-202 system generally relate one-to-one to single-unit employers in the Business Register and, hence, in the Economic Census. Multi-unit

\footnotetext{
${ }^{19}$ Inventory holdings act as a proxy for integration of information technology, which we do not observer directly. One advantage enjoyed by businesses with access to more sophisticated information technology (IT) networks is an enhanced ability (lower cost) to engage in more synchronized delivery of both inputs and outputs. Such scheduling abilities reduce the firm's need to hold costly inventories.
} 
employers on either side of the analysis are aggregated, but only within state, county and twodigit SIC.

Because of the sampling designs used in the ASM and BES, large establishments and large firms are over-represented in those surveys. However, three traits of the complex, linked pseudo-establishment dataset we construct make the establishment-level weights provided on the ASM and BES unsuitable for our analysis. First, the provided weights are establishment weights whereas our unit of observation is often some aggregation of those establishments, which we have called a pseudo-establishment. Establishments that were sampled into the ASM and BES may be combined with un-sampled establishments when we aggregate within-state multi-units to the pseudo-establishment level. Second, we use data from three states only. ${ }^{20}$ While samples such as the ASM and the BES are nationally representative by industry and size class if the provided weights are appropriately used, these surveys and weights were not designed to produce figures that are representative of certain industries and size classes in smaller geographic areas. Finally, match problems such as industry and geography coding discrepancies and differences in the scope of industries covered account for additional divergence in the universe as characterized by the LEHD infrastructure files and Economic Census-based samples.

To correct for the effects of non-uniform linking probabilities for the various source files used in our analysis samples, ex post weights were constructed as follows. First, we computed the fraction of employment by industry and establishment size class for establishments within the ES-202-based universe for which a human capital distribution can be calculated. ${ }^{21}$ This fraction is the numerator of the ex post weight. Second, we computed the fraction of employment by industry and establishment size class for establishments that were matched. This fraction is the denominator of the ex post weight. Such weights have the property that the weighted size distribution of employment by industry in our matched sample matches the size distribution of employment by industry in the ES-202 universe of establishments for which human capital distributions were computed.

\footnotetext{
${ }^{20} \mathrm{We}$ created firm level HC distributions and firm dynamics information for three states, California, Florida and Illinois, for the period 1992 through 1997. These were the only three states in the ALM data files that could be used consistently over the period spanning the two Economic Censuses (data for Florida are not available in 1992, instead we used the 1993 data as a proxy for 1992).

${ }^{21}$ The universe is all businesses in the ES202-based data sample that have at least five employees at the end of Q1 with $\mathrm{HC}$ estimates and are in Economic Census in-scope industries. We exclude the smaller establishments (fewer than five employees) from our analysis because we cannot compute within firm distributions of skill reliably for such businesses (i.e., no KDE estimates for the smallest units).
} 
We used the same weights in the dynamic specifications, even though the dynamic models were estimated for continuing establishments only, because the estimation sample includes later-year skill measures linked to 1992 business traits. Thus, the estimation sample is affected only by the point-in-time link between ES-202 data and the business surveys. For this reason, use of the same 1992 ex-post weights should correct for sampling and matching and, at a minimum, produce yearly estimates that are representative of continuing businesses that were alive in 1992.

\subsection{Selection Equations}

The ex post weighting does not correct for the behavioral consequences of businesses that exit. The partial adjustment model of equation (8) can only be estimated in each year using the sample of surviving businesses, and the ex post weight adjustments make this sample representative of continuers. However, it is possible that continuers differ from exiting businesses in some unmeasured way that is correlated with both technology spending and skill demand. Failure to account for this difference may produce biased estimates. For this reason, in the estimation of equations (3) and (8), we adjust for selection by estimating a separate exit selection equation for each year (1992 through 1996) using the sample of all pseudoestablishments that are active in 1992. We estimated this selection probit using the universe of businesses in the ES-202 data for 1992 that are both in-scope in industries covered by the ASM and the BES and that have at least five employees with HC estimates active at the end of Q1. The selection equation estimation is not restricted to the matched ASM and BES cases because selection is not modeled as a direct function of the observed technology. Instead, the likelihood of exit from the ES-202 universe from 1992 to 1996 is specified as a function of log labor productivity, the log change in population of the county in which the business is located between 1992 and the selection equation year (1992-1996), the log change in sales in the two digit SIC industry in that county between 1992 and 1997, and indicators for firm size, firm location (whether the business is located in a suburb, rural area, or central city in 1992), and legal form of organization (whether the firm is a sole proprietorship, partnership or corporation). In addition, all variables are interacted with an industry effect so that the impact of, say, size on exit is permitted to vary by industry (industry effects are at the major industry level of aggregation). The results of the selection analysis, while not reported, are sensible. For example, as is common in the firm dynamics selection literature, low labor productivity businesses are more likely to exit 
as are businesses in areas with increasing market demand. The probit estimates are then used to construct inverse Mills ratios that are included in the estimation of equations (3) and (8).

\subsection{Wage Rate Data}

We measure the shadow wage rate of skill group $b$ using the ratio of the county-level mean wage of the relevant skill group to the overall county mean wage for the county where each business is located. Thus, for example, if the skill group is the proportion of workers at the business above the economy-wide $75^{\text {th }}$ percentile (highest skill group), then we measure $w_{b j t} / w_{B j t}$ as the ratio of the county-level mean wage of workers above the $75^{\text {th }}$ percentile to the overall county-level mean wage. Separate wage rates were estimated for every skill group, state, county, and year in the estimation sample using the complete set of individuals available on our three-state UI wage record files.

\section{Human Capital and Technology: Basic Facts}

We now turn to the main point of the paper: exploring the influence of a firm's use of technology on its demand for human capital. The analysis is rich in the sense we delve into the relationship in multiple dimensions: by economic sector (manufacturing vs. service sectors); by skill level of the workforce (quartiles of our skill distributions); by type of skill level (overall, person effect and experience); by type of technology (capital per worker as well as indicators of newer, more computer-oriented technologies); by type of variation (between and within firm); and with and without selection controls.

How much variation is there in the levels of skill and technology across firms? Table 1a reports statistics that describe the manufacturing (ASM source) and service (BES source) distributions of human capital and the different measures of technology. ${ }^{22}$ In order to capture the heterogeneity across businesses, each business is ranked by its position in the distribution of the relevant measure, and we then report the $10^{\text {th }}, 50^{\text {th }}$ and $90^{\text {th }}$ percentile of that distribution. The results indicate substantial variation across businesses in both the distributions of skill and of technology. For example, in the manufacturing sector, the business at the $90^{\text {th }}$ percentile of the upper quartile person effect distribution has over 40 percent of its workers in the upper quartile while the $10^{\text {th }}$ percentile business has less than 10 percent). There is also evidence of substantial variation in computer intensity across businesses. The $10^{\text {th }}$ percentile firm in both the

\footnotetext{
${ }^{22}$ The results are weighted to be representative of the typical firm in the economy. Because the biggest firms employ by far the largest number of workers, this is very different from an employment-weighted sample.
} 
manufacturing and service sectors has zero percent of equipment investment in computers while the $90^{\text {th }}$ percentile business in each division has over 50 percent. $^{23}$

How important is selection likely to be in explaining changes in skill and technology over time? One striking feature that is uncovered by our analysis, and evident from an analysis of Table $1 \mathrm{~b}$ is that almost half of all businesses that existed in 1992 were no longer in business by 1997. This finding is quite consistent across sectors. Since previous work by ALM found that the distributions of human capital are very different across continuing, exiting and entering businesses, it is likely that these differences are in turn correlated with differences in the adoption of technology. ${ }^{24}$

In order to investigate this possibility, we first examine whether there are observably different patterns in the technology and skill mixes across businesses in the 1992 cross-section as a function of survival. The summary statistics for exiting businesses compared to continuers shown in Table 1 c make clear that exiting businesses do, in fact, look substantially different from continuing businesses. In particular, they tend to be smaller, less skill intensive (overall), and less technology intensive - particularly in computer and software investment in the manufacturing sector. Of interest is the fact that the different components of skill perform somewhat differently in the two sectors. Although exiting firms are uniformly less skill intensive (using the personeffect measure), manufacturing firms have both higher shares of lower quartile workers and of top quartile workers in terms of their person effects. The experience characteristics of the workforce are much less systematically related to exit. Technology measures also work differently in the two sectors in that businesses exiting manufacturing have much higher measures of the wage equation firm effect, $\psi$, than do continuing firms, while the opposite is true in the service sector. The results in Table 1c provide prima facie evidence that controlling for selection is likely to be important in analyzing across-firm differences.

The other potential source of variation in skill and technology across time is within-firm adjustment. As noted in section 2, the absence of key technology measures in 1997 limits our ability to examine the dynamic link between technology and worker skill. We do, however, have the same rich measures of human capital in 1993 through 1997 that are available to us in 1992,

\footnotetext{
${ }^{23}$ We also find (but do not report in Table 1a) that there are a number of businesses to the far right of this distribution that in 1992 spent all equipment investment on computers. This suggests that some businesses are actively upgrading to advanced technology in 1992 while others are not.

${ }^{24}$ The resulting selection issues are discussed in the next section.
} 
and these data permit us to examine how the distributions of different dimensions of skill at continuing businesses compare from one year to the next. This section, then, examines how differences in technology across businesses in 1992 is related to skill differences across businesses in 1992 and further examines how a given choice of skill and technology in 1992 is related to further adjustments in skill demand in the following years.

Table 1d presents a view of these relationships by providing 1995 human capital summary statistics for continuing businesses. A comparison of the 1995 medians to the 1992 medians for continuing businesses in Table 1c provides some insight into how the demand for worker skill changes over time, since this approach holds (approximately) constant the composition of the group over which the statistics are created. ${ }^{25}$ A comparison of the medians in Table 1d with the continuer columns in Table 1c reveals that the median continuer has markedly different skill demand in 1995 than in 1992. Continuers in both sectors demand an even lower share of low overall human capital workers and low experience workers and an even higher share of high human capital and high experience workers in 1995 than they did in 1992. The comparison of the distribution of skill as measured by the person effect reveals, however, that the pattern of increased demand for higher skilled workers varies across sectors. A very large fall (of nearly ten percentage points) in the share of bottom quartile person-effect workers is evident in manufacturing, combined with a rise of over six percentage points in the median share of high person-effect workers. The opposite pattern is the case in services: the median nonmanufacturing continuer has a median share of high person-effect workers that is nearly ten percentage points lower in 1995 than in 1992. These patterns indicate that, in addition to sizeable differences across types of businesses in the demand for skill, we also find that continuing businesses modify their human capital inputs over time as well.

\section{The Link between Technology and Human Capital}

This section discusses our estimates of equations (3) and (8). The first set of estimates presented below is based on the matched sample described in section 3 and uses the ex post weights ${ }^{26}$ constructed in the manner described in section $3 .^{27}$ Two sets of specifications were

\footnotetext{
${ }^{25}$ The two samples are only approximately equal due to firm deaths among the 1992 continuers group that occur during 1996 and 1997. These firms are still active and included in the calculations for continuers in Table 1d, while in Table 1c these firms are included in the exiters group.

${ }^{26}$ The estimation sample we use varies across sectors and specifications. In each case, steps must be taken to ensure that the estimated relationships between technology and skill are representative of the desired population. The procedure for developing ex post weights for establishments (or EIN county SIC pseudo-establishments in the
} 
estimated: one with and one without industry effects. Since the results are quite similar whether or not industry effects are included, only the latter are reported. Twelve different measures are used for the dependent variable in equation (3) - the share of workers at the business from each quartile of the 1992 economy-wide human capital distribution using three different measures of human capital. The between-firm relationship between technology adoption and workforce human capital is captured by means of estimating equation (3) using cross-sectional data for a sample of businesses. The ASM technology measures are used in the estimation for the manufacturing sector and for a sample of service sector businesses (retail trade, wholesale trade and services) the technology measures from the BES are used. All Table $2 \mathrm{a}$ and $2 \mathrm{~b}$ regression results control for $\log$ (sales), the county relative wage for the skill proportion that is the dependent variable, and indicator variables for business age as well as the variables shown in the tables. $^{28}$

Selection corrected results are also reported. The role the selection correction plays in the level (equation (3)) and partial adjustment (equation (8)) specifications is somewhat different. For the level model, the selection correction is included as a control for unobserved heterogeneity that may be simultaneously correlated with survival, human capital, and technology. For the partial adjustment model, the selection correction is a direct control for the sample selection induced by the use of continuers in the estimation of the partial adjustment specification. The reported standard errors are appropriately corrected for this two step procedure.

\subsection{Between Firm Variation: Findings from the Cross-section Model}

The results from the cross-section model containing all five technology measures as explanatory variables are reported in Tables $2 \mathrm{a}$ (without selection controls) and $2 \mathrm{~b}$ (with selection controls). These results demonstrate that there is a strong empirical relationship between technology and skill. Firms that use more technology employ a lower proportion of low-

case of multi-units) from the ES-202 data associated with the UI wage records is discussed in section 3. For the 1992 cross-sectional analysis, the ex post weights render the estimation sample representative of the same population that the ASM and BES represent. These same weights, when applied in estimating the partial adjustment model, lead to an estimation sample in each year that is representative of the yearly population of continuing (from 1992) businesses.

${ }^{27}$ This approach provides one way to exploit the variation in human capital and technology within and between industries reported (at least for human capital) in ALM (2003).

${ }^{28} \mathrm{We}$ tried specifications with all relative prices in the control variables. The results are not substantively different.. 
skill workers and a higher proportion of high-skill workers than do their non-technology using counterparts. To illustrate this finding, consider the role of computer investment in Table $2 \mathrm{~b}$. The estimated coefficients using the overall measure of skill for the top two quartiles are positive and for the bottom two quartiles are negative in both the manufacturing and service sectors. In the service sector, all of the estimated effects are statistically significant while for the manufacturing sector they are statistically significant for the top and second quartiles.

The novel aspect of the results is that the relationship between technology and skill differs substantially depending upon which measure of skill is used. We find, for example, that the relationships between computer investment and the person effect component of skill are very similar to those for the overall measure of skill. However, we find that firms with a higher proportion of computer investment are less likely to hire the most experienced workers (workers in the top quartile of experience). This finding holds up in spite of the controls for business age category, suggesting that the negative correlation between computer investment and worker experience is not simply the result of firm vintage effects.

These different patterns across the dimensions of skill are quantitatively important. Combining the summary statistics from Table $1 \mathrm{a}$ with the results from Table $2 \mathrm{~b}$ on the difference in computer investment between the $90^{\text {th }}$ percentile business and the $10^{\text {th }}$ percentile business shows that the implied difference in the share of workers in the highest quartile of the person effect distribution is about three percentage points higher at the $90^{\text {th }}$ percentile business. The analogous computation yields a five percentage point higher share of high person effect workers in services. These patterns hold for other measures of technology as well. For example, we find a positive relationship between skill and capital intensity in manufacturing and between inventories relative to sales and the software share in both sectors. More capital-intensive units are more likely to have highly skilled and less likely to have less skilled workforces using the overall measure of human capital. Alternatively, businesses holding more inventories in 1992 relative to sales are more likely to have low skilled and less likely to have high skilled workforces. Similar patterns hold for the software share.

The contrast in the person effect and the experience component of skill is also evident when alternative measures of technology are included. For example, although there is consistently a direct relationship between capital intensity and human capital in manufacturing, regardless of whether the overall measure or the person effect is used, the consistency is quite the 
opposite when the dependent variable is the experience measure of human capital. Not only is the relationship much less consistent, but in some cases (such as the demand for the third and fourth quartiles of the experience distribution in manufacturing), firms that have higher capital intensity have lower proportions of highly experienced workers.

The cross sectional specifications also have a variety of controls including a control for unmeasured technology, selection, and business age. The relationship between unmeasured technology, $\psi$, and human capital demand is positive in the uncorrected least squares regressions but negative in the selection-corrected specification. One possible reason for this result is that $\psi$ serves as proxy for unobserved heterogeneity, which may be related to entrepreneurial or managerial ability. Managerial ability might simultaneously drive the adoption of new technology and the employment of highly skilled workers.

Although the coefficients on the business age category controls are not reported in the regression tables, nearly all coefficients are found to be significant. The impact of business age on the various measures of skill demand is presented in Figure 1. These charts separately plot, for the bottom and top quartiles, the predicted demand by firm age-group for experience and skill (as measured through composite experience and the person effect components, respectively). Results for manufacturing and services are shown in separate graphs. The figures show that the demand for high person-effect workers is decreasing in firm age for service businesses and decreases monotonically with age among manufacturing businesses. Manufacturing businesses eleven to twenty-four years old demand fully six percent fewer top quartile person effect workers in 1992 than do the youngest businesses. The manufacturing demand for top-quartile experience workers is, in contrast, everywhere increasing in business age with businesses aged 11 to 24 demanding nearly ten percent more top quartile experience workers than do businesses that are no more than one year old. Exactly the opposite patterns are found for the predicted demand for low experience, low person-effect workers. Thus, it appears that workers with lower skill but more experience are more heavily concentrated at more mature businesses while younger businesses are more likely to employ high skilled workers with less experience.

A repeated theme in the reported results is that the relationship between technology and skill differs substantially depending on what measure of skill is used. For example, although there is consistently a direct relationship between capital intensity and human capital in manufacturing, regardless of whether the overall measure or the person effect is used, the 
consistency is quite the opposite when the dependent variable is the experience measure of human capital. Not only is the relationship much less consistent, but in some cases (such as the demand for the third and fourth quartiles of the experience distribution in manufacturing), firms that have higher capital intensity have lower proportions of highly experienced workers.

5.2 Adding Within Firm Variation in Human Capital: Findings from the Partial Adjustment Model

In order to examine within firm adjustment in the absence of broad 1997 technology measures, we take advantage of a major strength of our dataset - the availability of human capital measures in all years from 1992 to 1997 . We use the partial adjustment model specified in equation (8) to examine the relation between initial technology investment in 1992 and subsequent adjustments to skill demand among continuing firms. This approach permits us to examine whether skill demand for continuing businesses evolves over time in the anticipated way.

We estimated 48 separate partial adjustment equations (four skill quartiles by three skill measures by four years) for each of the two industry groups-manufacturing and services. In order to summarize the results, we present the full set of estimated coefficients, including the selection control variables, in Table 3 for one year (1995). We also present the implied changes in the demand for skills over time for one key right hand side variable, computer investment, in Figures $2 \mathrm{a}$ (manufacturing) and $2 \mathrm{~b}$ (services).

Starting with the results on computer investment, we find dynamic patterns that largely reinforce our cross sectional results. Controlling for 1992 skill demand, those businesses with higher levels of computer investment in 1992 have progressively higher estimated demand for the highest skilled workers from 1993 through 1996. Similarly, they demand a progressively lower share of the lowest skill workers. This finding holds for manufacturing and service sector businesses, regardless of whether we measure skill with the person effects or the composite measure. However, the finding is reversed when the skill measure is experience. In particular, as time passes since the investment, more computer intensive businesses in both sectors exchange their lowest experience workers for workers in the $2^{\text {nd }}$ quartile of the experience distribution. Thus, more computer intensive businesses shift towards workers with experience below the median, which is consistent with the cross-section results. 
The patterns of coefficients in Tables $2 \mathrm{~b}$ and 3 are quite similar, although, not surprisingly, the orders of magnitude of the coefficients in Table 3 are smaller, both because of the presence of 1992 skill level controls and because the relationship is only estimated over continuing firms. It is worth noting, however, that the implicit long run multiplier effects derived from Table 3 are quite large. For example, consider the impact of computer investment on the top quartile of skilled workers measured by person effects in non-manufacturing. The coefficient estimate in Table 3 is 0.0191 which compares to the cross-sectional estimate from Table $2 \mathrm{~b}$ of 0.0835. However, computing the long run multiplier for the Table 3 coefficient yields an implied effect of 0.095 . Thus, even when exploiting the within-firm variation in the demand for skills, we find large impacts of technology that varies by the different dimensions for skills.

\section{Concluding Remarks}

We began by raising a number of empirical questions. How sensitive is the demand for skilled workers to technological change? How sensitive is the demand for unskilled workers? Since skill has different dimensions - partly experience and partly basic ability - how is the demand for different types of skill affected?

This paper provides answers to some of these questions by using new measures of human capital matched to multiple measures of technology derived from substantial amounts of information about a firm's inputs and outputs. These data and measures were used to directly examine the way in which technology differences across businesses affect the types of workers that are employed in current and following years.

We found a strong positive empirical relationship between advanced technology and skill in a cross-sectional analysis of firms. While this latter result largely confirms the findings in the literature, it is worth emphasizing that our results hold using more comprehensive, richer measures of skill. Moreover, the more comprehensive measures of skill permitted investigating the relationship between skill and technology in a richer way. We found that advanced technology interacts with different components of skill quite differently: firms that use technology are more likely to use high-ability workers, but less likely to use high-experience workers. These results hold even controlling for unobservable heterogeneity by means of a selection correction and by using a partial adjustment specification.

In terms of specific measures of technology, the capital intensity, the computer investment, and the computer software expenditure intensity of a business are all positively 
related to the share of high-human-capital employment at the business. Accounting for changes in the demand for human capital across businesses is more difficult. This difficulty stems in part from data limitations in measuring changes in technology consistently across businesses, and in part from the persistent difference in the ways that firms organize themselves. We have tried to overcome these limitations by examining how technology spending in one year impacts the evolution of skill demand in later years. We found relationships that are consistent with those obtained in the cross section.

As always, more work remains to be done. The evidence in this research suggests that as firms adopt more technology they are less likely to employ experienced workers. This result has clear implications for the future as technology changes and the workforce ages: an important but relatively neglected topic in the literature on the relationship between skill and technology. The longitudinally-integrated employer-employee data used for the current analysis is ideal for such an undertaking, and the extension of the LEHD Program to a complete, national, longitudinal job frame is likely to yield many more insights. We regard this topic as a high priority for future research. 


\section{References}

Abowd, John M., Robert H. Creecy and Francis Kramarz, "Computing Person and Firm Effects Using Linked Longitudinal Employer-Employee Data," U.S. Census Bureau, LEHD Program Technical Paper TP-2002-06 (April 2002), available online at http://lehd.dsd.census.gov/led/library/techpapers/tp-2002-06.pdf (cited March 4, 2007).

Abowd, John M., Bruno Crépon and Francis Kramarz, "Moment Estimation with Attrition: An Application to Economic Models," Journal of the American Statistical Association, Vol. 96, No. 456 (December 2001): 1223-1231.

Abowd, John M., John Haltiwanger and Julia I. Lane, "Integrated Longitudinal EmployeeEmployer Data for the United States," American Economic Review Papers and Proceedings, Vol. 94, No. 2 (May 2004): 224-229.

Abowd, John M. and Francis Kramarz, "The Analysis of Labor Markets Using Matched EmployerEmployee Data," in O. Ashenfelter and D. Card (eds.) Handbook of Labor Economics, Volume 3(B), Chapter 40 (Amsterdam: North Holland, 1999), pp. 2629-2710.

Abowd, John M., Francis Kramarz and David Margolis, "High Wage Workers and High Wage Firms," Econometrica, Vol. 67, No. 2 (March 1999): 251-334.

Abowd, John M., Kevin L. McKinney and Paul A. Lengermann, "The Measurement of Human Capital in the U.S. Economy," U.S. Census Bureau, LEHD Program Technical Paper TP2002-09 (March 2003), available at http://lehd.dsd.census.gov/led/library/techpapers/tp2002-09.pdf (cited March 4, 2007).

Abowd, John M, Bryce E. Stephens, Lars Vilhuber, Fredrik Andersson, Kevin L. McKinney, Marc Roemer, and Simon Woodcock, "The LEHD Infrastructure Files and the Creation of the Quarterly Workforce Indicators" in T. Dunne, J.B. Jensen and M.J. Roberts, eds., Producer Dynamics: New Evidence from Micro Data (Chicago: University of Chicago Press for the National Bureau of Economic Research, forthcoming), available online from http://lehd.dsd.census.gov/led/library/techpapers/tp-2006-01.pdf (cited February 28, 2007).

Abowd, John M. and Lars Vilhuber, "The Sensitivity of Economic Statistics to Coding Errors in Personal Identifiers," Journal of Business and Economics Statistics, Vol. 23, No. 2 (April 2005): 133-152, JBES Joint Statistical Meetings invited paper with discussion and "Rejoinder" (April 2005): 162-165.

Audretsch, David B. and Talat Mahmood "New Firm Survival: New Results Using a Hazard Function," Review of Economics and Statistics, Vol. 77, No. 1 (February 1995): 97-103.

Autor, David, Lawrence Katz and Alan Krueger, "Computing Inequality: Have Computers Changed the Labor Market?” Quarterly Journal of Economics, 113 (November 1998): 1169-1214. 
Bartel, Ann P. and Frank R. Lichtenberg, "The Comparative Advantage of Educated Workers in Implementing New Technology," Review of Economics and Statistics, Vol. 69, No. 1 (February 1987): 1-11.

Bartelsman, Eric J., Randy A. Becker, and Wayne B. Gray, "NBER-CES Manufacturing Industry Database" (Cambridge: National Bureau of Economic Research, June 2000) available online at http://www.nber.org/nberces/nbprod96.htm (cited March 8, 2007).

Benedetto, Gary, John Haltiwanger, Julia Lane, and Kevin L. McKinney, "Using Worker Flows to Measure Firm Dynamics," Journal of Business and Economic Statistics (forthcoming) available at http://lehd.dsd.census.gov/led/library/techpapers/tp-2003-09.pdf (cited March 11, 2007).

Berman, Eli, John Bound and Zvi Griliches, "Changes in the Demand for Skilled Labor within U.S. Manufacturing Industries: Evidence from the Annual Survey of Manufacturing," Quarterly Journal of Economics, Vol. 109, No. 2 (May 1994): 367-398.

Bresnahan, Timothy, Brynjolfsson, Erik and Lorin M. Hitt, "Information Technology, Workplace Organization and the Demand for Skilled Labor: Firm-level Evidence," Quarterly Journal of Economics, Vol. 117, No. 1 (February 2002): 339-376.

Bureau of Labor Statistics, Handbook of Methods (2007), available online at http://www.bls.gov/opub/hom/homtoc_pdf.htm (cited February 28, 2007).

Caballero, Ricardo and Mohamad Hammour, "The Cleansing Effects of Recessions," American Economic Review, Vol. 84, No. 5 (December 1994): 1350-1368.

Campbell, Jeffrey R. "Entry, Exit, Embodied Technology, and Business Cycles," Review of Economic Dynamics, Vol. 1, No. 2 (April 1998): 371-408.

Caselli, Francesco, “Technological Revolutions,” American Economic Review, Vol. 89, No. 1 (March 1999): 78-102.

Chari, V.V. and Hugo Hopenhayn, "Vintage Human Capital, Growth, and the Diffusion of New Technology," Journal of Political Economy, Vol. 99, No. 6 (December 1991): 1142-65.

Davis, Steven J. and John C. Haltiwanger, "On the Driving Forces behind Cyclical Movements in Employment and Job Reallocation,” American Economic Review, Vol. 89, No. 5 (December 1999): 1234-1258.

Doms, Mark, Timothy Dunne and Kenneth R. Troske, "Workers, Wages, and Technology," The Quarterly Journal of Economics, Vol. 112, No. 1 (February 1997): 253-290.

Dunne, Timothy, Lucia Foster, John Haltiwanger, and Kenneth Troske, "Wage and Productivity Dispersion in U.S. Manufacturing: The Role of Computer Investment," NBER Working Paper No. 7465 (January 2000). 
Dunne, Timothy, John Haltiwanger and Kenneth R. Troske, "Technology and Jobs: Secular Change and Cyclical Dynamics," Carnegie-Rochester Public Policy Conference Series, 46 (June 1997): 107-178.

Dunne, Timothy, Mark J. Roberts and Larry Samuelson, "The Growth and Failure of U.S. Manufacturing Plants," The Quarterly Journal of Economics, Vol. 104, No. 4 (November 1989): 671-698.

Ehrenberg, Ronald and Robert S. Smith, Modern Labor Economics Theory and Public Policy, $9^{\text {th }}$ Edition (Boston, MA: Pearson Addison Wesley, 2005), summary available online at http://wps.aw.com/aw ehrensmith mlaborecon 9/0,10673,2445962-,00.html (cited March 4, 2007).

Ericson, Richard and Ariel Pakes, "Markov-Perfect Industry Dynamics: A Framework for Empirical Work.” Review of Economic Studies, Vol. 62, No. 1 (January 1995): 53-82.

Foster, Lucia, John Haltiwanger and C.J. Krizan, "Aggregate Productivity Growth: Lessons from Microeconomic Evidence," in Edward Dean, Michael Harper and Charles Hulten, eds., New Directions in Productivity Analysis (Chicago: University of Chicago Press, 2001), Chapter 8.

Haltiwanger, John C., Julia I. Lane and James R. Spletzer "Productivity Differences Across Employers: The Role of Employer Size, Age, and Human Capital," American Economic Review Papers and Proceedings, Vol. 89, No. 2 (May 1999): 94-98.

Haltiwanger, John C., Julia I. Lane and James R. Spletzer, "Wages, Productivity and the Dynamic Interaction of Businesses and Workers," Labour Economics (forthcoming).

Hellerstein, Judith K., David Neumark and Kenneth R. Troske, "Wages, Productivity, and Worker Characteristics: Evidence from Plant-Level Production Functions and Wage Equations." Journal of Labor Economics, Vol. 17, No. 3 (July 1999): 409-446.

Ichniowski, Casey, Kathryn Shaw and Giovanna Prennushi, "The Effects of Human Resource Management Practices on Productivity: A Study of Steel Finishing Lines," The American Economic Review, Vol. 87, No. 3 (June 1997): 291-313.

Jovanovic, Boyan and Glenn M. MacDonald, "The Life Cycle of a Competitive Industry," Journal of Political Economy, Vol. 102, No. 2 (April 1994): 322-47.

Juhn, Chinhui, Kevin M. Murphy and Brooks Pierce, "Wage Inequality and the Rise in the Return to Skill," Journal of Political Economy, Vol. 101, No. 3 (June 1993): 35-78.

Katz, Lawrence F. and Kevin Murphy, "Changes in Relative Wages, 1963-1987: Supply and Demand Factors," Quarterly Journal of Economics, Vol. 107, No. 1 (February 1992): 3578. 
Kremer, Michael and Eric Maskin, "Wage Inequality and Segregation by Skill,” NBER Working Paper, No. 5718 (August 1996).

Olley, G. Steven and Ariel Pakes, "The Dynamics of Productivity in the Telecommunications Equipment Industry,” Econometrica, Vol. 64, No. 6 (November 1996): 1263-1297.

Troske, Kenneth R. "The Worker-Establishment Characteristics Database," in Labor Statistics Measurement Issues, J. Haltiwanger, M. Manser, and R. Topel, eds., (Chicago: University of Chicago Press, 1998), pp. 371-403. 
Figure 1
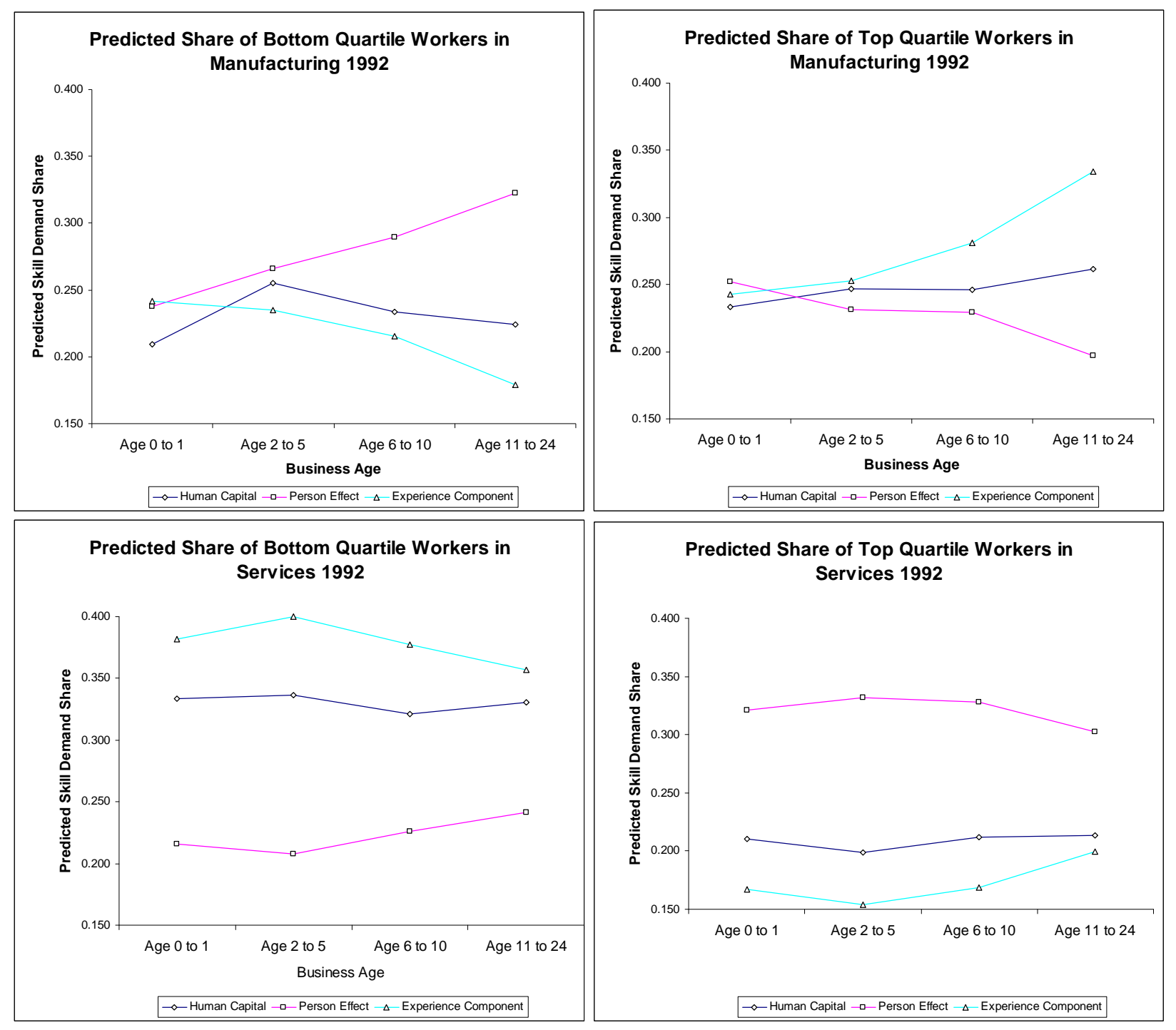


\section{Figure 2a}

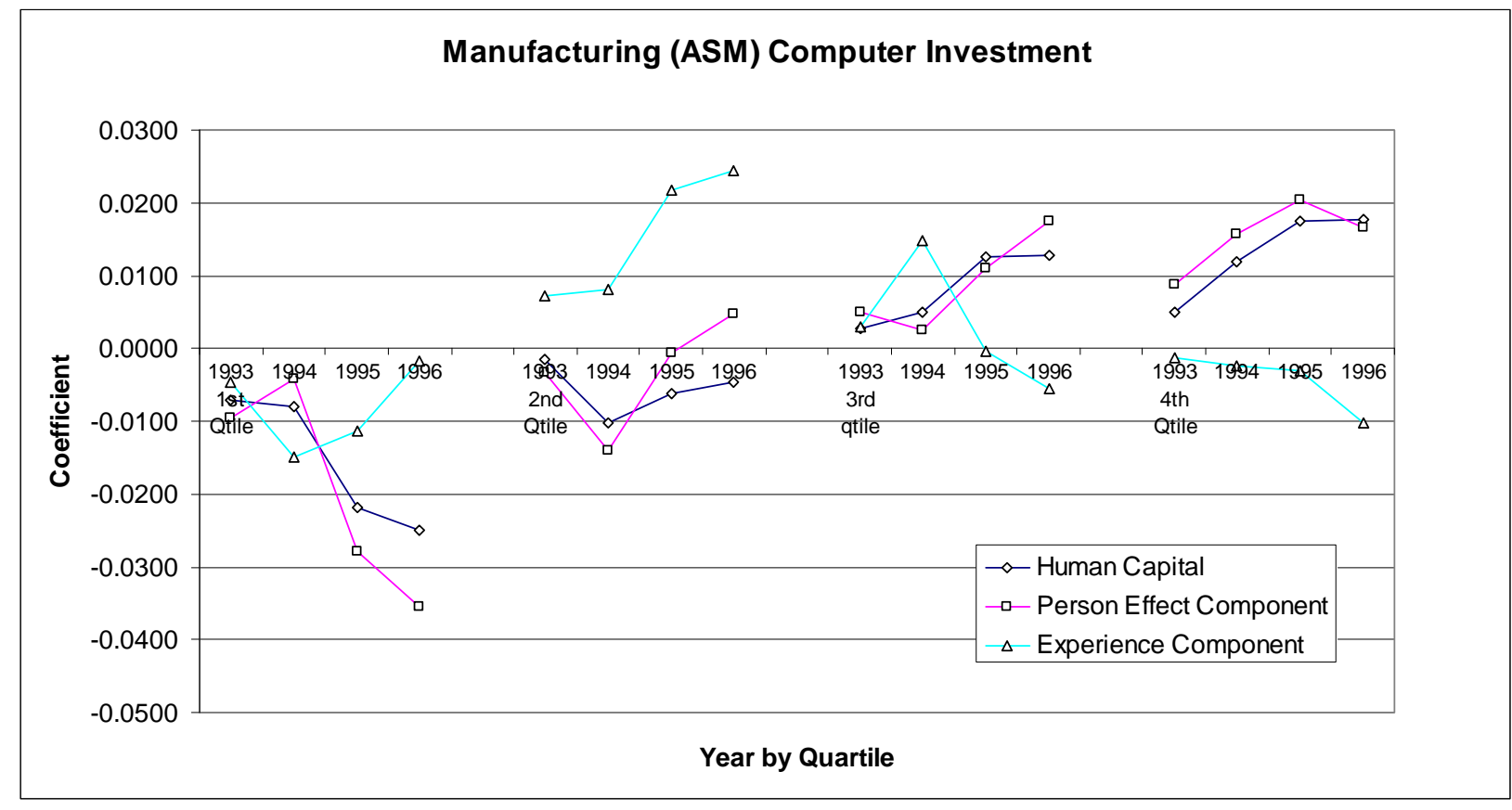

Figure 2b

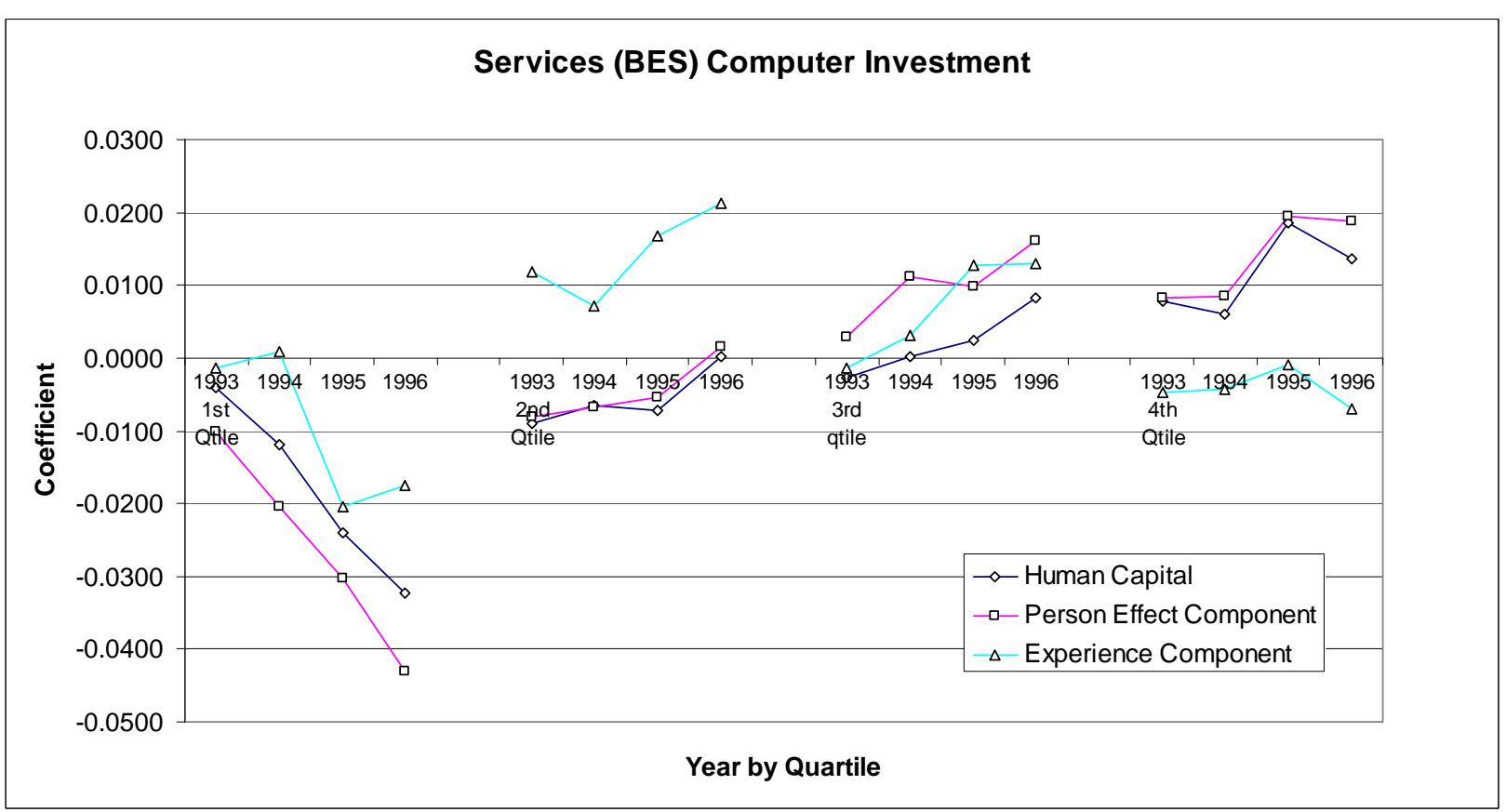




\begin{tabular}{|c|c|c|c|c|c|c|}
\hline \multicolumn{4}{|c|}{$\begin{array}{c}\text { Table 1a: } 1992 \text { Summary Statistics for Human Capital and } \\
\text { Annual Survey of Manufactures } \\
\qquad 0^{\text {th }}\end{array}$} & \multicolumn{3}{|c|}{ Business Expenditures Survey } \\
\hline 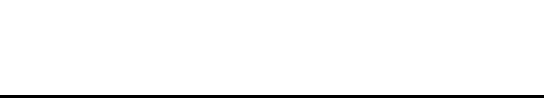 & $\begin{array}{c}10^{\text {th }} \\
\text { percentile }\end{array}$ & $\begin{array}{c}50^{\text {th }} \\
\text { percentile }\end{array}$ & $\begin{array}{c}90^{\text {th }} \\
\text { percentile }\end{array}$ & $\begin{array}{c}10^{\text {th }} \\
\text { percentile }\end{array}$ & $\begin{array}{c}50^{\text {th }} \\
\text { percentile }\end{array}$ & $\begin{array}{c}90^{\text {th }} \\
\text { percentile }\end{array}$ \\
\hline $\begin{array}{l}\text { Proportion of workforce in bottom } \\
\text { quartile of human capital (overall) }\end{array}$ & 0.054 & 0.178 & 0.434 & 0.087 & 0.307 & 0.581 \\
\hline $\begin{array}{l}\text { Proportion of workforce in second } \\
\text { quartile of human capital (overall) }\end{array}$ & 0.135 & 0.232 & 0.352 & 0.140 & 0.236 & 0.341 \\
\hline $\begin{array}{l}\text { Proportion of workforce in third quartile } \\
\text { of human capital (overall) }\end{array}$ & 0.141 & 0.258 & 0.408 & 0.097 & 0.206 & 0.343 \\
\hline $\begin{array}{l}\text { Proportion of workforce in fourth } \\
\text { quartile of human capital (overall) }\end{array}$ & 0.099 & 0.260 & 0.469 & 0.035 & 0.182 & 0.455 \\
\hline $\begin{array}{l}\text { Proportion of workforce in bottom } \\
\text { quartile of human capital (person effect) }\end{array}$ & 0.071 & 0.211 & 0.473 & 0.081 & 0.268 & 0.506 \\
\hline $\begin{array}{l}\text { Proportion of workforce in second } \\
\text { quartile of human capital (person effect) }\end{array}$ & 0.146 & 0.239 & 0.357 & 0.141 & 0.242 & 0.352 \\
\hline $\begin{array}{l}\text { Proportion of workforce in third quartile } \\
\text { of human capital (person effect) }\end{array}$ & 0.131 & 0.239 & 0.377 & 0.124 & 0.217 & 0.339 \\
\hline $\begin{array}{l}\text { Proportion of workforce in fourth } \\
\text { quartile of human capital (person effect) }\end{array}$ & 0.094 & 0.241 & 0.443 & 0.063 & 0.210 & 0.470 \\
\hline $\begin{array}{l}\text { Proportion of workforce in bottom } \\
\text { quartile of human capital (experience) }\end{array}$ & 0.079 & 0.185 & 0.351 & 0.128 & 0.341 & 0.627 \\
\hline $\begin{array}{l}\text { Proportion of workforce in second } \\
\text { quartile of human capital (experience) }\end{array}$ & 0.194 & 0.271 & 0.351 & 0.159 & 0.259 & 0.367 \\
\hline $\begin{array}{l}\text { Proportion of workforce in third quartile } \\
\text { of human capital (experience) }\end{array}$ & 0.140 & 0.214 & 0.289 & 0.070 & 0.153 & 0.265 \\
\hline $\begin{array}{l}\text { Proportion of workforce in fourth } \\
\text { quartile of human capital (experience) }\end{array}$ & 0.190 & 0.305 & 0.425 & 0.086 & 0.200 & 0.356 \\
\hline Log Sales & 6.745 & 8.434 & 10.486 & 6.016 & 7.506 & 9.520 \\
\hline Computer Investment Share & 0.000 & 0.024 & 0.551 & 0.000 & 0.025 & 0.580 \\
\hline Software Share (x100) & 0.000 & 0.000 & 0.004 & 0.000 & 0.000 & 0.000 \\
\hline Log Capital Intensity & 2.512 & 4.006 & 5.228 & 2.152 & 3.765 & 10.173 \\
\hline Inventory/Sales & 0.024 & 0.094 & 0.285 & 0.000 & 0.007 & 0.203 \\
\hline$\Psi$, wage equation firm effect & -0.140 & 0.151 & 0.391 & -0.520 & -0.033 & 0.328 \\
\hline $\begin{array}{l}\text { Notes: Percentiles are based upon match } \\
\text { use our ex post sample weights. Sample } \\
\text { Percentiles reported in this and subseque } \\
\text { centered on the reported percentile. }\end{array}$ & $\begin{array}{l}\text { samples } \\
\text { s are } 4,6 \\
\text { ables ref }\end{array}$ & $\begin{array}{l}\text { h betwe } \\
\text { eudo-es } \\
\text { ne weigl }\end{array}$ & $\begin{array}{l}\text { S-202/U } \\
\text { hments } \\
\text { Iverage c }\end{array}$ & $\begin{array}{l}\text { ASM an } \\
\text { nufactur } \\
\text { value in }\end{array}$ & $\begin{array}{l}\text {-202/UI } \\
\text { nd } 9,460 \\
\text { hree perc }\end{array}$ & $\begin{array}{l}\text { BES) and } \\
\text { ervices. } \\
\text { les }\end{array}$ \\
\hline
\end{tabular}




\begin{tabular}{|lr|}
\hline $\begin{array}{l}\text { Table 1b: Share of Businesses (by Sector) that Exit } \\
\text { between 1992 and } 1997\end{array}$ \\
\hline & Share Exiting \\
Sector & Businesses \\
Manufacturing & 0.445 \\
Retail Trade & 0.505 \\
Wholesale Trade & 0.473 \\
Services & 0.478 \\
\hline Source: Authors' calculations from the ES-202 universe. \\
\hline
\end{tabular}


Table 1c: 1992 Summary Statistics for Continuing and Exiting (by 1997) Businesses

\begin{tabular}{|c|c|c|c|c|}
\hline & \multicolumn{2}{|c|}{$\begin{array}{l}\text { Manufacturing } \\
50^{\text {th }} \text { percentile }\end{array}$} & \multicolumn{2}{|c|}{$\begin{array}{c}\text { Services } \\
50^{\text {th }} \text { percentile }\end{array}$} \\
\hline & Continuers & Exiters & Continuers & Exiters \\
\hline $\begin{array}{l}\text { Proportion of workforce in bottom quartile of } \\
\text { human capital (overall) }\end{array}$ & 0.184 & 0.208 & 0.289 & 0.339 \\
\hline $\begin{array}{l}\text { Proportion of workforce in second quartile of } \\
\text { human capital (overall) }\end{array}$ & 0.245 & 0.242 & 0.238 & 0.236 \\
\hline $\begin{array}{l}\text { Proportion of workforce in third quartile of } \\
\text { human capital (overall) }\end{array}$ & 0.258 & 0.254 & 0.210 & 0.199 \\
\hline $\begin{array}{l}\text { Proportion of workforce in fourth quartile of } \\
\text { human capital (overall) }\end{array}$ & 0.240 & 0.214 & 0.185 & 0.161 \\
\hline $\begin{array}{l}\text { Proportion of workforce in bottom quartile of } \\
\text { human capital (person effect) }\end{array}$ & 0.286 & 0.312 & 0.210 & 0.226 \\
\hline $\begin{array}{l}\text { Proportion of workforce in second quartile of } \\
\text { human capital (person effect) }\end{array}$ & 0.269 & 0.264 & 0.219 & 0.217 \\
\hline $\begin{array}{l}\text { Proportion of workforce in third quartile of } \\
\text { human capital (person effect) }\end{array}$ & 0.215 & 0.208 & 0.232 & 0.223 \\
\hline $\begin{array}{l}\text { Proportion of workforce in fourth quartile of } \\
\text { human capital (person effect) }\end{array}$ & 0.188 & 0.177 & 0.292 & 0.279 \\
\hline $\begin{array}{l}\text { Proportion of workforce in bottom quartile of } \\
\text { human capital (experience) }\end{array}$ & 0.185 & 0.178 & 0.328 & 0.337 \\
\hline $\begin{array}{l}\text { Proportion of workforce in second quartile of } \\
\text { human capital (experience) }\end{array}$ & 0.235 & 0.237 & 0.231 & 0.229 \\
\hline $\begin{array}{l}\text { Proportion of workforce in third quartile of } \\
\text { human capital (experience) }\end{array}$ & 0.246 & 0.248 & 0.194 & 0.187 \\
\hline $\begin{array}{l}\text { Proportion of workforce in fourth quartile of } \\
\text { human capital (experience) }\end{array}$ & 0.298 & 0.296 & 0.181 & 0.171 \\
\hline Log Sales & 8.461 & 8.377 & 7.646 & 7.199 \\
\hline Computer Investment Share & 0.026 & 0.015 & 0.025 & 0.027 \\
\hline Software Share (x100) & 0.000 & 0.000 & 0.000 & 0.000 \\
\hline Log Capital Intensity & 4.022 & 4.028 & 3.839 & 3.484 \\
\hline Inventory/Sales & 0.093 & 0.096 & 0.006 & 0.010 \\
\hline$\Psi$, wage equation firm effect & 0.132 & 0.181 & -0.019 & -0.042 \\
\hline Sample size & 2,659 & 1,984 & 5,618 & 4,022 \\
\hline
\end{tabular}




\section{Table 1d: 1995 Human Capital Summary Statistics for Continuing Businesses}

Proportion of workforce in bottom quartile of human capital (overall)

Proportion of workforce in second quartile of human capital (overall) Annual Survey of Manufactures Business Expenditures Survey $10^{\text {th }} \quad 50^{\text {th }} \quad 90^{\text {th }}$ percentile percentile percentile $10^{\text {th }} \quad 50^{\text {th }} \quad 90^{\text {th }}$ Proportion of workforce in third quartile of human capital (overall) Proportion of workforce in fourth quartile of human capital (overall)

Proportion of workforce in bottom quartile of human capital (person effect)

Proportion of workforce in second quartile of human capital (person effect)

Proportion of workforce in third quartile of human capital (person effect)

Proportion of workforce in fourth quartile of human capital (person effect)

Proportion of workforce in bottom quartile of human capital (experience)

0.039

0.148

percentil percentile percentile

Proportion of workforce in second quartile of human capital (experience)

0.124

0.237

0.404

0.064

0.260

0.561

0.124

0.237

0.371

0.140

0.243

0.354

0.142

0.278

0.437

0.105

0.220

0.368

0.103

0.261

0.485

0.045

0.196

0.471

0.067

0.201

0.469

0.147

0.250

0.378

0.074

0.255

0.505

0.132

0.248

0.400

0.149

0.254

0.369

0.090

0.224

0.434

0.050

0.149

0.296

0.126

0.222

0.360

Proportion of workforce in third quartile of human capital (experience)

Proportion of workforce in fourth quartile of human capital (experience)

$\begin{array}{lll}0.174 & 0.250 & 0.335 \\ 0.169 & 0.238 & 0.317 \\ 0.217 & 0.338 & 0.468\end{array}$

0.059

0.200

0.461

Notes: Percentiles are based upon matched samples (match between ES-202/UI and ASM and ES-202/UI and BES) and use our ex post sample weights. Sample sizes are 3,248 pseudo-establishments in manufacturing and 6,402 in services. 


\begin{tabular}{|c|c|c|c|c|c|c|c|c|}
\hline & First Q & uartile & Second & $\overline{\text { Quartile }}$ & Third & uartile & Fourth & Quartile \\
\hline & Manuf. & Services & Manuf. & Services & Manuf. & Services & Manuf. & Services \\
\hline Total Human Capital & & & & & & & & \\
\hline Capital Intensity & $-0.0474 *$ & $-0.0066^{*}$ & $-0.0181^{*}$ & $-0.0011^{*}$ & $0.0246^{*}$ & $0.0014 *$ & $0.0391 *$ & $0.0066^{*}$ \\
\hline & 0.0021 & 0.0005 & 0.0014 & 0.0003 & 0.0015 & 0.0003 & 0.0022 & 0.0005 \\
\hline Computer Investment Share & $-0.0259 *$ & $-0.0671 *$ & $-0.0251 *$ & $-0.0177 *$ & 0.0015 & 0.0064 & $0.0548 *$ & $0.0784 *$ \\
\hline & 0.0078 & 0.0064 & 0.0051 & 0.0036 & 0.0056 & 0.004 & 0.0083 & 0.0061 \\
\hline Inventory/Sales & $-0.0413 *$ & $-0.1113 *$ & 0.0002 & 0.0058 & -0.0058 & $0.0760 *$ & $0.0334 *$ & $0.0279 *$ \\
\hline & 0.0134 & 0.014 & 0.0087 & 0.008 & 0.0096 & 0.0087 & 0.0142 & 0.0133 \\
\hline Software Share & -0.045 & $-0.4788^{*}$ & $-1.0853^{*}$ & $0.3767 *$ & $-1.2177 *$ & 0.0011 & $2.7053^{*}$ & 0.0734 \\
\hline & 0.438 & 0.2659 & 0.2846 & 0.1517 & 0.3161 & 0.1651 & 0.4652 & 0.2534 \\
\hline$\Psi$, wage equation firm effect & $-0.1901^{*}$ & $-0.2521 *$ & -0.0094 & $-0.0282 *$ & $0.1220 *$ & $0.0988 *$ & 0.0938 & $0.1819 *$ \\
\hline & 0.0104 & 0.0049 & 0.0068 & 0.0028 & 0.0075 & 0.0031 & 0.011 & 0.0047 \\
\hline Person Effect & & & & & & & & \\
\hline Capital Intensity & $-0.0553^{*}$ & $-0.0028 *$ & $-0.0071^{*}$ & $-0.0014^{*}$ & $0.0256^{*}$ & -0.0003 & $0.0351 *$ & $0.0048 *$ \\
\hline & 0.0022 & 0.0005 & 0.0013 & 0.0003 & 0.0014 & 0.0003 & 0.0022 & 0.0005 \\
\hline Computer Investment Share & $-0.0399 *$ & $-0.0589 *$ & -0.0082 & $-0.0265^{*}$ & -0.0055 & 0.0037 & $0.0579 *$ & $0.0830 *$ \\
\hline & 0.0083 & 0.006 & 0.005 & 0.0038 & 0.0053 & 0.0038 & 0.0081 & 0.0062 \\
\hline Inventory/Sales & -0.0129 & $-0.1208 *$ & 0.0029 & $0.0263 *$ & -0.019 & 0.0847 & 0.0185 & 0.0081 \\
\hline & 0.0143 & 0.0132 & 0.0085 & 0.0083 & 0.0091 & 0.0084 & 0.0138 & 0.0136 \\
\hline Software Share & 0.035 & $-0.5661 *$ & $-1.7203^{*}$ & -0.0049 & $-0.7323 *$ & 0.0287 & $2.6976^{*}$ & $0.5305 *$ \\
\hline & 0.4686 & 0.2517 & 0.279 & 0.1582 & 0.2977 & 0.1604 & 0.4545 & 0.2596 \\
\hline$\Psi$, wage equation firm effect & $-0.1699 *$ & $-0.1513 *$ & $0.0273^{*}$ & $-0.0301^{*}$ & $0.1011^{*}$ & $0.0418 *$ & $0.0553 *$ & $0.1418^{*}$ \\
\hline & 0.0111 & 0.0047 & 0.0067 & 0.003 & 0.0071 & 0.003 & 0.0108 & 0.0048 \\
\hline Experience & & & & & & & & \\
\hline Capital Intensity & $-0.0051^{*}$ & $-0.0098 *$ & $-0.0066^{*}$ & $0.0028 *$ & -0.0011 & $0.0035^{*}$ & $0.0137 *$ & $0.0034 *$ \\
\hline & 0.0017 & 0.0006 & 0.0011 & 0.0003 & 0.0009 & 0.0003 & 0.0014 & 0.0004 \\
\hline Computer Investment Share & 0.0006 & $-0.0162 *$ & $0.0237^{*}$ & $0.0189 *$ & -0.0022 & 0.0082 & $-0.0224 *$ & $-0.0113^{*}$ \\
\hline & 0.0062 & 0.0075 & 0.0041 & 0.0036 & 0.0035 & 0.0033 & 0.0052 & 0.0044 \\
\hline Inventory/Sales & $-0.0750 *$ & -0.019 & $0.0167 *$ & $-0.0549 *$ & $0.0307 *$ & -0.0075 & $0.0255^{*}$ & $0.0813 *$ \\
\hline & 0.0106 & 0.0165 & 0.0069 & 0.0078 & 0.006 & 0.0072 & 0.0089 & 0.0096 \\
\hline Software Share & -0.2963 & 0.4908 & -0.4288 & -0.2246 & $1.0326^{*}$ & -0.0662 & -0.313 & -0.201 \\
\hline & 0.3471 & 0.3134 & 0.2282 & 0.1488 & 0.1967 & 0.1373 & 0.2915 & 0.1828 \\
\hline$\Psi$, wage equation firm effect & $-0.0860 *$ & $-0.2154 *$ & $-0.0160 *$ & $0.0549 *$ & $0.0102 *$ & $0.0518 *$ & $0.0911 *$ & $0.1082 *$ \\
\hline & 0.0082 & 0.0058 & 0.0054 & 0.0028 & 0.0047 & 0.0026 & 0.0069 & 0.0034 \\
\hline $\begin{array}{l}\text { Note: All models control for } \\
\text { sample weights. Sample sizes } \\
\text { are statistically significant at } \\
\text { models control for business a } \\
11 \text { to } 24 \text { years and age } 25 \text { or c } \\
\text { pseudo-establishments, the ag } \\
\text { digit SIC unit }\end{array}$ & $\begin{array}{l}\text { les) and } \\
643 \text { pse } \\
\text { e percer } \\
\text { indicato } \\
\text { For sin } \\
\text { ables ca }\end{array}$ & $\begin{array}{l}\text { e county } \\
\text {-establi } \\
\text { evel are } \\
\text { riables: } \\
\text { unit bus } \\
\text { re the as }\end{array}$ & $\begin{array}{l}\text { red and } \\
\text { year or } \\
\text { sses, the } \\
\text { f the old }\end{array}$ & efficien & $\begin{array}{l}\text { d stand } \\
\text { two to } \\
\text { the est }\end{array}$ & $\begin{array}{l}\text { ror ar } \\
\text { years, } \\
\text { ament }\end{array}$ & For $\mathrm{n}$ & $\begin{array}{l}\text { ex post } \\
\text { ts that } \\
\text { All } \\
\text { ars, age } \\
\text { unit } \\
\text { y, two- }\end{array}$ \\
\hline
\end{tabular}




\begin{tabular}{|c|c|c|c|c|c|c|c|c|}
\hline & \multicolumn{2}{|c|}{ First Quartile } & \multicolumn{2}{|c|}{ Second Quartile } & \multicolumn{2}{|c|}{ Third Quartile } & \multicolumn{2}{|c|}{ Fourth Quartile } \\
\hline & Manuf. & Services & Manuf. & Services & Manuf. & Services & Manuf. & Services \\
\hline \multicolumn{9}{|l|}{ Total Human Capital } \\
\hline \multirow[t]{2}{*}{ Capital Intensity } & $-0.0473 *$ & -0.0064 & $-0.0181^{*}$ & -0.0012 & $0.0246^{*}$ & 0.0014 & $0.0391 *$ & 0.0065 \\
\hline & 0.0066 & 0.0066 & 0.0046 & 0.0037 & 0.0052 & 0.0041 & 0.007 & 0.0062 \\
\hline \multirow[t]{2}{*}{ Computer Investment Share } & -0.0253 & $-0.0678 *$ & $-0.0250 *$ & $-0.0176^{*}$ & 0.0012 & $0.0066^{*}$ & $0.0542 *$ & $0.0789 *$ \\
\hline & 0.0138 & 0.0018 & 0.0096 & 0.0010 & 0.0108 & 0.0011 & 0.0146 & 0.0017 \\
\hline \multirow[t]{2}{*}{ Inventory/Sales } & $-0.0395 *$ & $-0.1133^{*}$ & 0.0004 & 0.0061 & -0.0063 & $0.0765^{*}$ & $0.0322 *$ & $0.0292 *$ \\
\hline & 0.0044 & 0.0059 & 0.0031 & 0.0033 & 0.0034 & 0.0037 & 0.0047 & 0.0056 \\
\hline \multirow[t]{2}{*}{ Software Share } & $-0.1649 *$ & $-0.4987^{*}$ & $-1.0995^{*}$ & $0.3797 *$ & $-1.1726^{*}$ & 0.006 & $2.8011^{*}$ & $0.0863 *$ \\
\hline & 0.0063 & 0.0112 & 0.0044 & 0.0063 & 0.0049 & 0.0069 & 0.0067 & 0.0105 \\
\hline \multirow[t]{2}{*}{$\Psi$, wage equation firm effect } & -0.0069 & -0.0071 & $0.0264 *$ & $0.0070 *$ & -0.0087 & 0.0031 & -0.0147 & -0.0028 \\
\hline & 0.0102 & 0.005 & 0.0071 & 0.0028 & 0.008 & 0.0031 & 0.0107 & 0.0047 \\
\hline \multirow[t]{2}{*}{ Inverse Mills Ratio } & $-0.0216^{*}$ & $-0.0063^{*}$ & -0.0027 & $0.0009^{*}$ & $0.0087^{*}$ & 0.0016 & $0.0181 *$ & $0.0041 *$ \\
\hline & 0.0022 & 0.0005 & 0.0015 & 0.0003 & 0.0017 & 0.0003 & 0.0024 & 0.0005 \\
\hline \multicolumn{9}{|l|}{ Person Effect } \\
\hline \multirow[t]{2}{*}{ Capital Intensity } & $-0.0552 *$ & -0.0026 & -0.0071 & -0.0014 & $0.0256^{*}$ & -0.0004 & $0.0350 *$ & 0.0047 \\
\hline & 0.0072 & 0.0064 & 0.0045 & 0.0039 & 0.0047 & 0.004 & 0.0067 & 0.0064 \\
\hline \multirow[t]{2}{*}{ Computer Investment Share } & $-0.0392 *$ & $-0.0598^{*}$ & -0.0082 & $-0.0265^{*}$ & -0.0057 & $0.0041 *$ & $0.0573 *$ & $0.0835 *$ \\
\hline & 0.015 & 0.0017 & 0.0094 & 0.0010 & 0.0098 & 0.0011 & 0.0141 & 0.0017 \\
\hline \multirow[t]{2}{*}{ Inventory/Sales } & $-0.0112 *$ & $-0.1234^{*}$ & 0.0029 & $0.0263^{*}$ & $-0.0195^{*}$ & $0.0860^{*}$ & $0.0175^{*}$ & 0.0094 \\
\hline & 0.0048 & 0.0057 & 0.003 & 0.0035 & 0.0031 & 0.0036 & 0.0045 & 0.0057 \\
\hline \multirow[t]{2}{*}{ Software Share } & $-0.0888^{*}$ & $-0.5913^{*}$ & $-1.7254^{*}$ & -0.0048 & $-0.6855^{*}$ & $0.0405^{*}$ & $2.7832 *$ & $0.5430 *$ \\
\hline & 0.0069 & 0.0109 & 0.0043 & 0.0066 & 0.0045 & 0.0068 & 0.0064 & 0.0109 \\
\hline \multirow{2}{*}{$\Psi$, wage equation firm effect } & $-0.0329 *$ & -0.0003 & $0.0288 *$ & -0.0012 & -0.0011 & 0.0002 & 0.0026 & 0.0021 \\
\hline & 0.0111 & 0.0048 & 0.0069 & 0.0029 & 0.0073 & 0.003 & 0.0104 & 0.0048 \\
\hline \multirow[t]{2}{*}{ Inverse Mills Ratio } & $-0.0227^{*}$ & $-0.0080 *$ & -0.001 & 0.0000 & $0.0088 *$ & $0.0038^{*}$ & $0.0167 *$ & $0.0040 *$ \\
\hline & 0.0024 & 0.0005 & 0.0015 & 0.0003 & 0.0016 & 0.0003 & 0.0023 & 0.0005 \\
\hline \multicolumn{9}{|l|}{ Experience } \\
\hline \multirow[t]{2}{*}{ Capital Intensity } & -0.0051 & -0.0099 & -0.0066 & 0.0028 & -0.0011 & 0.0036 & $0.0137 *$ & 0.0034 \\
\hline & 0.0049 & 0.0083 & 0.0031 & 0.0037 & 0.0028 & 0.0035 & 0.0043 & 0.0046 \\
\hline \multirow[t]{2}{*}{ Computer Investment Share } & 0.0007 & -0.016 & $0.0238^{*}$ & $0.0190 *$ & -0.0022 & $0.0082 *$ & $-0.0226^{*}$ & $-0.0115^{*}$ \\
\hline & 0.0103 & 0.0022 & 0.0066 & & 0.0059 & & 0.0091 & 0.0012 \\
\hline \multirow[t]{2}{*}{ Inventory/Sales } & $-0.0749 *$ & $-0.0185^{*}$ & $0.0169 *$ & $-0.0547 *$ & $0.0308 *$ & $-0.0076 *$ & $0.0251 *$ & $0.0808 *$ \\
\hline & 0.0033 & 0.0074 & 0.0021 & 0.0033 & 0.0019 & 31 & 0.0029 & 0.0041 \\
\hline \multirow[t]{2}{*}{ Software Share } & $-0.3031^{*}$ & $0.4958^{*}$ & $-0.4473^{*}$ & $-0.2224 *$ & $1.0298 *$ & -0.0675 & $-0.2833^{*}$ & -0.2056 \\
\hline & 0.0047 & 0.014 & 0.003 & 0.0062 & 0.0027 & 0.0058 & 0.0042 & 0.0078 \\
\hline$\Psi$, wage equation firm effect & $0.0554 *$ & $0.0163 *$ & 0.0001 & $-0.0115^{*}$ & $-0.0334 *$ & -0.01 & $-0.0224 *$ & 0.0052 \\
\hline & 0.0076 & 0.0062 & 0.0048 & 0.0028 & 0.0043 & 0.0026 & 0.0067 & 0.0035 \\
\hline Inverse Mills Ratio & -0.0013 & $0.0016^{*}$ & $-0.0036^{*}$ & $0.0007 *$ & -0.0005 & -0.0004 & $0.0058 *$ & $-0.0015^{*}$ \\
\hline & 0.0017 & 0.0007 & 0.0011 & 0.0003 & 0.0009 & 0.0003 & 0.0015 & 0.0004 \\
\hline $\begin{array}{l}\text { Note: All models control fo } \\
\text { sample weights. Sample size } \\
\text { are statistically significant at } \\
\text { models control for business } \\
11 \text { to } 24 \text { years and age } 25 \text { or } \\
\text { pseudo-establishments, the a }\end{array}$ & $\begin{array}{l}\text { indicato } \\
\text { For sin } \\
\text { iables ca }\end{array}$ & $\begin{array}{l}\text { riables: } \\
\text {-unit bu } \\
\text { re the a }\end{array}$ & $\begin{array}{l}\text { year o } \\
\text { sses, th }\end{array}$ & meas & the est & ment & For $m$ & $\begin{array}{l}\text { ex post } \\
\text { ts that } \\
\text { All } \\
\text { ars, age } \\
\text { unit } \\
\text { y, two- }\end{array}$ \\
\hline
\end{tabular}


Table 3: Regression of Skill Mix on Technology --1995 Continuers, With Selection and 1992 Controls

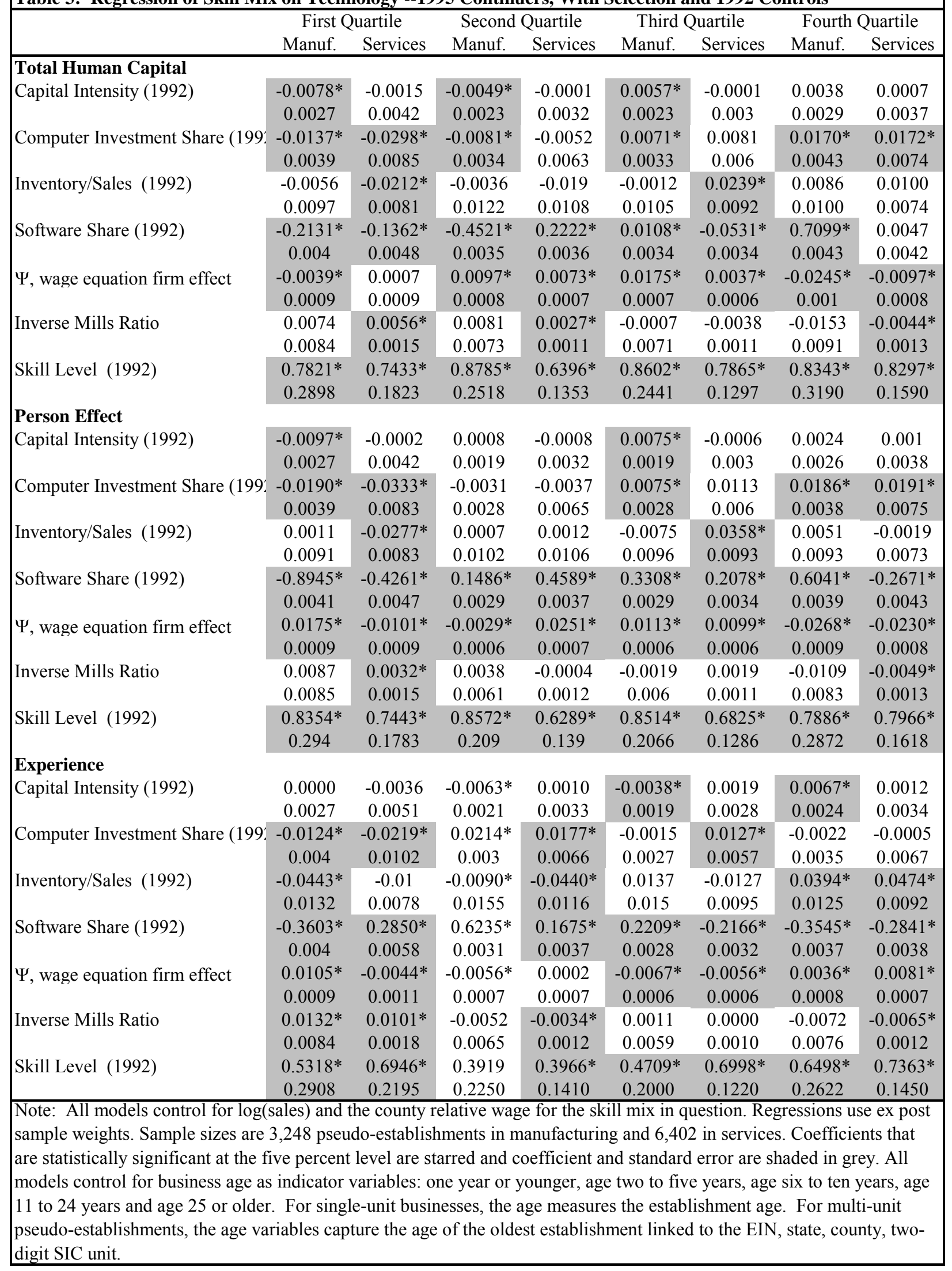

